\title{
Wettability of bio-coke by coal tar pitch for its use in carbon anodes
}

\author{
Xianai Huang, Duygu Kocaefe*, Yasar Kocaefe, Dipankar Bhattacharyay \\ UQAC/AAI Research Chair on Carbon and REGAL Aluminum Research Center \\ University of Québec at Chicoutimi 555 Boulevard de l'Université, Chicoutimi, QC, Canada G7H 2B1 \\ Xianai Huang <xianai.huang1@uqac.ca>, \\ Duygu Kocaefe <duygu_kocaefe@uqac.ca>, \\ Yasar Kocaefe<yasar_kocaefe@uqac.ca>, \\ Dipankar Bhattacharyay < dipankar.bhattacharyay1@uqac.ca> \\ Corresponding author: Tel 1 418-545 5011 ext. 5215 \\ E-mail: duygu_kocaefe@uqac.ca
}

\begin{abstract}
Information on the wettability of a bio-coke substrate is of great value in assessing the possibility of using that bio-coke as a potential raw material for carbon anode production. In this study, the interaction mechanisms of a coal tar pitch with six bio-coke substrates were studied at a coke-pitch mixing temperature of $170^{\circ} \mathrm{C}$, an average industrial value, by means of a sessile-drop test. Three bio-cokes were produced from different bio-materials by pyrolysing to $426^{\circ} \mathrm{C}$, and the other three by further calcining them to $1200^{\circ} \mathrm{C}$. Different techniques were used to analyze the structural and chemical characteristics of the six bio-cokes. The results show that the heat treatment temperature has a significant influence on the chemical properties of biocokes and the wettability of pitch/bio-coke systems. The possibility of partial replacement of petroleum coke by bio-coke is discussed on the point view of the structure and wettability results.
\end{abstract}

Keywords: Bio-coke, Carbon/carbon composites, Contact angle, coal tar pitch, surface characterization, Interface

\section{Introduction}

Carbon anodes consumed during the alumina electrolysis for aluminum production are manufactured by mixing, vibro-compacting, and finally baking a mixture of calcined petroleum coke, coal tar pitch, and recycled materials (rejected anodes and butts) [1,2]. Calcined petroleum coke is one of the main raw materials used in producing carbon anodes, and its properties are important because they directly affect the quality of anodes, the cost, and the environmental emissions. New sources of carbon materials with desired properties are being sought to reduce emissions. Bio-cokes, carbon materials derived from biomasses, are low in cost, considered renewable, abundant in supply, and readily available around the globe. Potentially, the partial replacement of petroleum coke by bio-coke, produced from a lignocellulosic material and a renewable natural resource, as filler would reduce the cost and the emissions during the carbon anode fabrication for aluminum production [3].

Taking into consideration the relevant properties and the requirements in various applications, different biomass materials have been studied to produce bio-carbon materials [4, 5]. Researchers have used biomass materials to generate activated bio-carbon materials and have studied their utility in many major technologies such as environmental protection (sorbent of dyes and heavy metals [6, 7]) and energy storage (electrode material for super capacitors [8]). However, due to their high specific surface area and consequently high absorption capacity [8], bio-activated carbon materials are mostly used as sorbents in environmental protection. A few studies are reported in the literature on some of the properties of electrode grade carbons prepared with biocokes made from different biomass materials [1, 3, 9-16]. Bio-coke and bio-pitch, produced by pyrolyzing Eucalyptus wood, were used as renewable sources to make small experimental electrodes [1]. It was reported that the electrodes produced by bio-coke and bio-pitch had comparable electrical and mechanical properties to those made with conventional carbonaceous materials [1]. Emmerich et al. [15] have employed babassu coconuts to generate carbon material, and they found that it showed similar Young's modulus and rupture strength with those observed in electrodes produced using conventional cokes. As the carbon anodes in aluminum industry are consumed during the electrolytic process, anodes made with petroleum coke contribute to carbon and sulfur oxide emissions. However, the bio-coke which is a sulfur-free renewable raw material does not contribute to environmental emissions [9]. Thus, the current emissions could be reduced through the partial replacement of petroleum coke with bio-coke [3]. However, the published literature on the use of bio-coke in anodes used for aluminum production is rare [12, 17]. Monsenet et al. [12] has studied the possibility of replacing petroleum coke with bio-cokes produced from maple and spruce to make pilot scale anodes and then to produce aluminum. They reported that the low density of bio-coke affected the anode properties adversely, 
and it did not decrease significantly the $\mathrm{CO}_{2}$ emissions during anode consumption. In a previous study by the authors of the current article, the structural and morphological characterization of two bio-cokes was carried out in order to compare with those of two calcined petroleum cokes. It was found that bio-coke seems to have a suitable structure to be used as raw material for anodes utilized in aluminum industry [17].

Wettability of coke by pitch is influenced by their surface properties; and the degree of wetting is of considerable practical and economic significance for understanding the interactions between the filler and the binder that occur during mixing. This is one of the important steps which determine the final properties of a carbon anode [18]. This information also gives an idea of the different pitch and coke characteristics required in order to improve the quality of final material. This might constitute an important criterion for the selection of a particular coke or pitch for a given application. A number of investigations were carried out on the wettability of petroleum coke by pitch during mixing at different temperatures. The results showed that the wettability depends on the physicochemical properties of pitch, the nature and surface properties of coke, and the condition of the baking process [18-28]. The effect of the properties and the process temperature of petroleum coke on its interaction with pitch during the mixing stage was studied by many researchers $[18,26,28]$. Wettability is normally assessed based on the pitch behavior during the initial stages of a penetration test [22]. The contact angle between a pitch droplet and a bed of fine coke particles or the change in the height of the pitch droplet with time is recorded as the temperature is increased during the test $[18,21,24,27]$. The temperature at which the contact angle becomes $90^{\circ}$ is determined as the wetting temperature of the pitch. However, this kind of test does not provide enough information on the true wettability of a coke by a pitch. It was reported from the isothermal penetration experiments that the contact angle continuously changes from greater than $90^{\circ}$ to less than $90^{\circ}$, even to $0^{\circ}$, at a constant temperature $[22,28]$. The quantitative characterization of the true spreading and penetration capacity of a pitch is required. Studies which quantify the dynamic wetting process for a pitch on a coke bed are rare. Sarkar et al. [28] studied the dynamic wettability and interaction of different cokes by pitch. However, there is no quantitative study on the spreading and penetration properties of pitch on either petroleum coke or bio-coke. The dynamic wetting process of bio-coke by pitch is not fully understood.

It was reported that bio-coke usually exhibits low density and high porosity compared to petroleum coke [12], which might contribute to the wettability if the open pores of bio-coke can be successfully filled with pitch during mixing. However, high porosity might also decrease the density of a coke and increase the pitch requirement, which may, in turn, decrease the anode density and increase the cost for anode production. As explained previously, various studies were carried out on the utility of bio-carbon as sorbent and the wettability of petroleum coke by pitch. To the authors' knowledge, the published literature about the wettability of bio-coke by pitch at the mixing stage is still lacking. Moreover, a detailed and comprehensive analysis of the wettability of bio-coke by pitch and the chemical analysis of bio-coke are not available in the literature. In addition, the difference between the wettability of bio-coke or petroleum coke by pitch is not completely clear. The current study aims to fill this void and to evaluate quantitatively the dynamic wettability of different bio-cokes prepared using different raw materials and temperatures by coal tar pitch.

In this paper, pitch wettability on a bio-coke substrate at $170^{\circ} \mathrm{C}$ (approximate coke/pitch mixing temperature used in the aluminum industry) is studied by using a sessile-drop experimental system to understand their interactions. This could lead to the production of better quality carbon anodes for use in the primary aluminum industry. A typical coal tar pitch was used; and six bio-cokes, of which three were produced via heat treatment to $426^{\circ} \mathrm{C}$ of biomasses from different sources and the other three by further calcining them to $1200^{\circ} \mathrm{C}$, were tested as substrates.

A dynamic wetting model was used to describe and quantify the spreading and penetration ability (wetting capacity) of the pitch on all bio-coke beds.

The model can be expressed as [29, 30]:

$$
\theta=\frac{\theta_{i} \theta_{e}}{\theta_{i}+\left(\theta_{e}-\theta_{i}\right) \exp \left(K\left(\frac{\theta_{e}}{\theta_{e}-\theta_{i}}\right) t\right)}
$$

where $\theta_{i}$ is the initial contact angle, $\theta_{e}$ is the apparent equilibrium contact angle, $K$ is the penetration and spreading rate constant, and $t$ is the total penetration time. Because of the continuous changes of contact angle during wetting due to the penetration of pitch on coke particle bed, it is impossible to measure the real equilibrium contact angle on this pitch-coke bed system. Therefore, the equilibrium contact angle $\theta_{e}$ was determined as a contact angle measured at a same time after the drop is deposited on the coke bed for all the samples. Here, the time of 200s was chosen due to the total wetting times and the characteristics of contact angle-time curves for the samples in this study so that the K-value can characterize as much as possible the whole wetting system for all the samples and also can be compared each other. Spreading and penetration for a given pitch-coke system can be quantified if the $K$-value is known. A higher $K$-value indicates that the pitch penetrates and spreads faster (increased wetting). 
The effects of the structure and the chemical composition of the bio-cokes on the wettability were also studied. Optical microscopy (OPM), scanning electron spectroscopy (SEM), Fourier transforms infrared spectroscopy (FTIR), and X-ray photoelectron spectroscopy (XPS) were used to establish the relationship between the characteristics of the bio-cokes and its wettability by coal tar pitch.

\section{Material and methods}

\subsection{Materials used}

The raw materials and the pyrolysis and calcination conditions of the bio-coke production process used in this study are summarized in Table 1. Three bio-coke samples received from Boisaco Inc. (identified in this article as 'uncalcined bio-coke' to separate them from the other three that were calcined at the University of Quebec at Chicoutimi (UQAC) were studied (no. 1-3 in Table 1). Bio-coke-1 was obtained from leafy trees and bio-coke2 from softwood trees. According to the information received, the pyrolysis of these three samples was carried out at the maximum temperature of $426^{\circ} \mathrm{C}$; no other detail on the pyrolysis process is available. The calcined bio-coke samples (no. 4-6 in Table 1) were produced by calcining the uncalcined bio-coke samples to $1200^{\circ} \mathrm{C}$ in the lab at UQAC. The details of the calcination process are discussed below (see also Table 1). The wettabilities of one sample of calcined petroleum coke and one sample of wood chips were also studied (no.7 and no. 8 in Table 1, respectively) for comparison purposes. A coal-tar pitch which is currently used as the binder by the aluminum industry was utilized. Specimens for the experimental study were arbitrarily selected for a complete statistical randomization. Samples were divided and sieved to different ranges of particle sizes. The particle sizes within the range of $600-1000 \mu \mathrm{m}$ were used for the investigation of their structures with the optical microscope in this study. They were stored in a room at $20^{\circ} \mathrm{C}$ and $40 \%$ relative humidity prior to the characterization tests described below.

\subsection{Calcination of bio-coke}

The bio-coke samples received from Boisaco Inc. were calcined to $1200^{\circ} \mathrm{C}$ in a thermogravimetric analyzer with induction heating (TGA induction) at the University of Quebec at Chicoutimi (UQAC) at a high heating rate which is typically used for green petroleum coke calcination. In industry, the green petroleum coke is calcined to high temperatures (usually $>1200^{\circ} \mathrm{C}$ ). The green carbon anodes, which are made of petroleum coke and coal tar pitch, are baked in large furnaces up to $1050^{\circ} \mathrm{C}$ to $1200^{\circ} \mathrm{C}$ to produce baked anodes. If the coke is not previously calcined to a temperature above the anode baking temperature, it will still undergo structural modification and devolatilization during the anode baking process. This might cause further pore formation in coke particles and consequently in anodes, resulting in a decrease in anode quality. Since the original bio-coke samples were produced at $426^{\circ} \mathrm{C}$, the objective was to investigate the effect of calcination (high temperature treatment) on the wetting properties of bio-cokes. The bio-coke sample was put in a carbon crucible which was supported by metal wires and then suspended from a balance for measuring the weight loss of the sample during calcination. The nitrogen gas was used as the carrier gas to protect the sample in TGA during induction heating. The nitrogen enters the furnace from the bottom. The conditions of calcination, such as the maximum temperature of $1200^{\circ} \mathrm{C}$, the heating rate of $40^{\circ} \mathrm{C} / \mathrm{min}$ and $15 \mathrm{~min}$. of holding time at the maximum temperature, were chosen so as to simulate the industrial conditions used in the calcination of petroleum coke. The difference between the properties of bio-cokes heat-treated under different temperatures and heating rates can further be studied to improve the process for bio-coke production in such a system.

\subsection{Wettability tests}

The wettability experiments were performed by carrying out contact angle measurements. The contact angles between pitch and bio-coke were determined using a sessile-drop experimental system. This system consists of a tube furnace (Thermolyne 21100), an Inconel tube with a pitch injection system, a graphite crucible for the sample (sample holder for the substrate), a digital video camera (B/W) (APPRO, model KC), and a secondary rotary vacuum pump (GE, Precision Vacuum Pump, Model D25). Bio-coke powder was placed in the sample holder. The metal injection chamber holds the solid pitch sample. This chamber has a small hole at the bottom and was placed just above the substrate during the experiment.

In this study, one coal tar pitch and six different bio-coke samples were tested. Bio-coke particles were ground, and an average particle size of 125 microns was used for the wetting test. This particle size was used in accordance with the results of previous studies [28]. The particles were compacted in the sample crucible in order to have a smooth bio-coke bed surface. The experiments were conducted under nitrogen $\left(\mathrm{N}_{2}\right)$ atmosphere for protection purposes. There were two entry lines for nitrogen. The main line was directly connected to the inlet tube for maintaining the inert atmosphere inside this tube. The other line, connecting the injection chamber to the inert gas supply, carried the $\mathrm{N}_{2}$ gas necessary for slightly pressurizing this chamber in order to force the liquid pitch out onto the solid sample. Pitch was ground and put in the injection chamber which is also made of graphite and located just above the sample. At the beginning, the position of the hole was upwards to be able to 
keep the pitch in the injection chamber when it melts. When the furnace was heated to the desired temperature, the molten pitch droplet was dropped directly onto the bio-coke substrate by moving the position of the injection chamber hole to downward position. The drop size can be changed by adjusting the hole size of the chamber and the pressure difference between two chambers. The sample holder can be removed from the hot region of the furnace via a specially designed mechanism, and the sample can be quenched for further analysis. The system uses video image processing which makes the rapid determination of dynamic contact angles possible compared to the conventional contact angle goniometry. The initial period after trigger was $0.033 \mathrm{~s}$ and the post-trigger period multiplier was set to 1.1. A video of the drop was captured over a period of 25 minutes. The system can capture both static and dynamic images. To measure the contact angle, the FTA 32 software is used. In order to minimize the $\mathrm{O}_{2}$ and humidity contents of nitrogen, it was passed through $\mathrm{O}_{2}$ (Chromatographic Specialties, Oxygen Trap C36084) and humidity traps (Chromatographic Specialties, Glass Moisture Trap - C36150) before it entered the system. The sessile drop experiments were carried out at $170^{\circ} \mathrm{C}$. Two or three tests were performed for each set of experimental conditions. The contact angles between each droplet and the specimen (substrate) surface were measured both on the left side and the right side of the droplet, and the mean contact angles were automatically calculated. When the contact angles at the same time for different repetitions are smaller than $5{ }^{\circ} \mathrm{C}$, the data were accepted and used to calculate the average contact angle. Images of the drop in contact with the substrate were continuously captured at full video speed. The dynamic contact-angle data were used to assess the wettability.

Eq. (2) can be obtained from Eq. (1). K-values of the pitch-bio-coke system were determined by curve-fitting the experimental data to Eq. (2) using a nonlinear approach. The apparent equilibrium contact angle measured at $200 \mathrm{~s}$ was used in Eq. (2) in order to solve for the K-value. An example of calculation of K-value for petroleum coke was showed in Figure 1.

$$
\frac{\theta_{e}-\theta_{i}}{\theta_{e}} \ln \frac{\theta-\theta_{e}}{\theta}=K t-\frac{\theta_{e}-\theta_{i}}{\theta_{e}} \ln \frac{\theta_{i}}{\theta_{i}-\theta_{e}}
$$

The objective of this study is to explain the wettability results with respect to the structural and chemical nature of the coke samples. Tools used for the physical characterization of the coke particles and the particle-pitch interface are optical microscopy and SEM. Tools used for chemical characterization of the coke particles and pitch are FTIR and XPS.

\subsection{Analysis of optical microscopy images}

The epoxy liquid resin was chosen for the preparation of polished blocks for both bio-coke and petroleum coke samples to be characterized in this study. Polishing was carried out using Struers polisher to create a scratch free surface. Afterwards, a Nikon Eclipse ME600 optical microscope (Nikon Inc., Melville, NY) with a total of 1000X magnification was used to analyze the particle morphology. Composite images were obtained from the digital camera attached to the microscope and operated with Optical Image Analyzer (Clemex JS-2000).

\subsection{SEM examination}

To prepare sample surfaces for SEM, all small test samples without polishing were mounted onto the surface of an aluminum block with dimensions of $20 \mathrm{~mm} \times 30 \mathrm{~mm}$ using electrically conducting paste. The test pieces were cleaned with a high pressure dust-removing gas to remove the surface debris and to provide a stronger attachment to the electrically conducting paste. For electrical conduction, all samples were sputter-coated with a palladium/gold layer $(20 \mathrm{~nm})$ and then mounted onto standard aluminum stubs using electrically conducting paste. The samples were scanned using a Jeol scanning electron microscope (JSM 6480LV) with a magnification up to $300000 \times$ at the accelerating voltage of $10 \mathrm{kV}$. The distance between the sample and the electron microscope head was $10-25 \mathrm{~mm}$ with a spot size of 40 . The specimen temperature was approximately $20^{\circ} \mathrm{C}$, and the column vacuum was $6.66 \times 10^{4} \mathrm{~Pa}$. Electron micrographs of both tangential and radial surfaces in the longitudinal direction for bio-cokes and wood chips were taken. SEM micrographs of different surfaces of petroleum cokes were also taken to investigate the difference from those of bio-cokes in different directions.

\subsection{FTIR spectroscopy analysis}

In this study, the chemical structure of different bio-coke samples was examined by FTIR spectroscopy at room temperature. In addition, the chemical structure of one wood sample (see Table 1) was also examined using the FTIR analysis in order to compare with those of bio-coke and determine the modifications taking place during the bio-coke manufacturing process. The main objective was to identify the new bond formation in bio-coke which could potentially be used in anode production. IR spectra were collected in the wave number range of 400-4000 $\mathrm{cm}^{-1}$, and all the spectra were recorded at $4 \mathrm{~cm}^{-1}$ resolution. Each time, 20 scans were carried out prior to the Fourier transformation. All spectra were collected using a KBr technique (Perkin Elmer Instrument, Spectrum One), and the results considered were the average of two experiments. The samples were mixed with 
$\mathrm{KBr}$ at a ratio of 1:100. Then, the mixture was pressed to a pellet form for FTIR analysis. All spectra were analyzed using the spectrum version 5.0.1 software. The IR spectra for each experimental set were transformed into the absorbance spectra.

\subsection{XPS spectroscopy analysis}

XPS analyzes the surface to a depth of about 1-20 nm and provides information about the chemical states (bonding and oxidation), surface composition as well as the location of atom types within the samples [31]. It has been used previously to investigate the changes after the chemical treatment of numerous lignocellulosic materials, and in particular, of polymers with functionally modified surfaces [31-33]. Different bio-coke samples were grounded to $125 \mu \mathrm{m}$. All preparations were carried out avoiding all contact with bare hands, and the samples were immediately placed in air-tight plastic bags. The XPS measurements were performed with AXIS Ultra XPS spectrometer (Kratos Analytical) at the Alberta Centre for Surface Engineering and Science (ACSES) of the University of Alberta. The detailed analysis procedure and parameters used were described in previous publication [28]. CASAXPS software was utilized for data processing. A linear background was subtracted from each peak. Then the peak area was evaluated and scaled to the instrument sensitivity factors. The composition was calculated from the survey spectra with the sum of all peaks after scaling equal to $100 \%$. The spectra fitting and component analysis were performed using the high-resolution spectra. The number of components and their binding-energy positions were used in component identification according to the finding of Sarkar et el.[28]. As the binding energy value may change slightly based on the presence of different atoms adjacent to the carbon atom, ranges rather than specific positions were selected for different functional groups.

\section{Results and discussion}

\subsection{Wettability test}

In order to examine the pitch/bio-coke interactions at the mixing stage in detail, pitch/bio-coke wetting behavior was studied by investigating different indicators, namely, dynamic contact angle during wetting, initial contact angle, contact angle at $100 \mathrm{~s}$, percent decrease in contact angle at 100s as well as K-value. This study permits a comprehensive characterization of pitch/bio-coke wetting behavior.

\subsubsection{Bio-coke wettability characterized by dynamic contact angle}

The wetting experiments were carried out using a coal tar pitch on six bio-coke substrates: three pyrolyzed biocokes (samples as received before calcination, no. 1-3 in Table 1) and three calcined bio-cokes (after calcination of pyrolyzed samples, no. 4-6 in Table 1). The dynamic contact angles were recorded. This information is useful for understanding the wetting and the penetration mechanism of pitch into bio-coke. During this project, the effect of calcination on the dynamic contact angle, initial contact angle, total wetting time (when contact angle becomes zero), and the K-value were studied. Furthermore, the effect of the bio-coke feedstock type on the wettability was also investigated. The results were compared with those of a petroleum coke using the same pitch for all substrates.

Figures 2(a), 2(b), and 2(c) present the dynamic contact angles as a function of time for bio-coke-1, bio-coke-2, and bio-coke-3, respectively, with the same pitch before and after calcination. As can be seen in all three figures, the high temperature calcination reduces the wettability of bio-cokes; consequently, the contact angles of calcined bio-cokes are higher than those of uncalcined bio-cokes for each species. The increase in the contact angles after calcination depends on the species for all the three bio-cokes. As shown in Figure 2 (a), the contact angles of bio-coke-1 before and after calcination do not seem to differ significantly at the initial stage of wetting; however, the difference continues to increase with time and becomes significant rapidly. The differences in contact angles between before and after calcinations are much smaller at all times for bio-coke-2 and bio-coke-3 (see Figure 2 (b) and (c)) compared to that of bio-coke-1 (see Figure 2 (a)). These results show that the effect of calcination on the wettability of bio-coke by pitch differs according to the type of bio-coke feedstock although the trends observed for bio-cokes originating from softwood and hardwood species are found to be similar (see Figure 2 (b) and (c)).

Figure 3 shows the dynamic contact angles obtained for wood chips, three bio-cokes calcined to $1200^{\circ} \mathrm{C}$, and the petroleum coke with a coal tar pitch. This petroleum coke was chosen for comparison since it was found to be wetted best by the pitch used during this study compared to all other petroleum cokes previously studied [28]. The contact angles between pitch and calcined bio-cokes and petroleum coke are higher than those between the same pitch and wood chips at an early time (100 s), which means that the bio-coke samples lost part of their wettability during pyrolysis and calcination. The results show that the contact angles for different calcined biocokes differ at different times. At early times, the calcined samples of bio-coke- 1 and bio-coke- 3 have contact angles similar to those of petroleum coke up to $100 \mathrm{~s}$, whereas calcined bio-coke-2 exhibits higher contact angles than those of petroleum coke. At longer times, the comparison of contact angles between calcined bio- 
cokes and petroleum coke can be explained in terms of two factors depending on different carbon precursors. The contact angles found for calcined bio-coke- 1 and petroleum coke with pitch are similar at any given time and decrease as time increases. However, the decrease in contact angles with time seems to be more significant for wood chips, calcined bio-cokes 2 and 3 with the same pitch. As can be seen from the above results, biocokes produced from hard and softwoods are wetted better than the bio-coke obtained from leafy trees and the petroleum coke by a given pitch. Lignin, hemicellulose, and cellulose are three main components for the biological lignocellulosic materials such as leafy trees and hard/softwoods used in this study. The hemicellulose and cellulose, namely carbohydrate, is bound to lignin intimately. All the three components contribute to the aromatic carbon content during the carbonization of bio-coke. The chemical structure and composites of these above-mentioned components are different. Lignin has higher aromatic carbon content (60-63\%) than the other two components ( 40\%) [34]. Thus, the contents of these components differ in different carbon precursors, which contribute to variation in the behavior of bio-cokes. One of the consequences is the differences observed in the wettability of different bio-coke samples by pitch.

\subsubsection{Bio-coke wettability characterized by initial contact angles and total wetting time}

The common mixing time of pitch and coke in aluminum industry is of that order of $100 \mathrm{~s}$. Thus, the contact angles at $100 \mathrm{~s}$ and the percent decrease in a contact angle from initial time to $100 \mathrm{~s}$ are crucial indexes for the investigation of the wetting property of pitch into coke particles during mixing processing. The total wetting time describes the characteristics of whole wetting of pitch on coke surface, which is important to understand the penetration of pitch into coke particles and pores in cokes during the overall anode making processing. The initial contact angles, contact angles at $100 \mathrm{~s}$, the percent decrease in a contact angle from $0 \mathrm{~s}$ to $100 \mathrm{~s}$, and the times at which the complete wetting (the complete submergence of liquid drop into substrate) took place for all three bio-cokes before and after calcination as well as for the petroleum coke are presented in Table 2 . As can be seen from this table, the values of the initial contact angles as well as the ones at $100 \mathrm{~s}$ found for calcined biocokes prepared from different carbon precursors are higher than those of uncalcined bio-cokes while percent decrease in contact angle is significant only in the case of bio-coke 1. Higher percentage of decrease in a contact angle indicates faster penetration of pitch into a coke bed and, hence, better wettability. Bio-cokes show greater percentage of decrease in contact angles compared to the petroleum coke after $100 \mathrm{~s}$. The percent decrease in contact angle for three different bio-cokes were found to be different. In addition, the percent decrease in contact angles is greater up to $100 \mathrm{~s}$ for calcined bio-cokes compared to those for uncalcined ones. The results indicate that high temperature treatment influences the wettability of bio-cokes by pitch.

The uncalcined bio-coke samples exhibit different total wetting times depending on the feedstock, ranging from $325.5 \mathrm{~s}$ for bio-coke-3 to $594.4 \mathrm{~s}$ for bio-coke-1. The total wetting times of all calcined bio-coke samples are longer than those of uncalcined bio-cokes of the same origin. This result suggests that the calcination to $1200^{\circ} \mathrm{C}$ reduces the penetration of pitch through bio-coke beds differently; consequently, the increase in the total wetting time varies depending on the sample. According to Rocha et al. [18], the distillation and polymerization of coke during heat treatment result in the reduction in hydrogen content and carbon enrichment. The subsequent polymerization of the coke components increases their aromaticity, which contribute to the reduction in coke wettability by pitch [18]. The results show that the wettability of five bio-cokes (uncalcined and calcined) by the coal tar pitch is higher than that of petroleum coke used during this study with the exception of calcined biocoke-1.

\subsubsection{Bio-coke wettability analysis based on K-value}

K-value was used to study the spreading and penetration mechanism of pitch on bio-coke beds at a same given time. A higher K-value indicates that the contact angle reaches equilibrium more rapidly and the liquid (pitch) spreads and penetrates faster into the solid (bio-coke bed). In other words, a higher K-value means increased wetting. Figure 5 compares the K-values of the bio-cokes (before and after calcination) and the petroleum coke. The K-values of the uncalcined bio-cokes are higher than those of the calcined bio-cokes for all three species respectively but to different extents, which is in agreement with the above contact angle results. The difference between the K-values of calcined and uncalcined bio-cokes is smallest for bio-coke-2. Bio-coke-2 and bio-coke3 have higher K-values than those of both calcined and uncalcined bio-coke- 1 . These results show that the changes due to calcination in the spreading and penetration of pitch depend on the type of lignocellulosic materials. It can also be observed that the K-values of all bio-cokes with the exception of the calcined bio-coke1 are higher than that of the petroleum coke, which means pitch has better spreading and penetration ability through nearly all the bio-cokes than through the petroleum coke. These results imply that both bio-cokes ( 2 and 3 ), in calcined and uncalcined forms, have the potential for use in anode manufacturing from the point of view of their wettability by pitch.

It was reported that high temperature treatment has a significant influence on the structural properties of petroleum coke, and consequently, on the wettability of coke by pitch [18, 27]. Calcination at high temperature brings about changes not only in the physical properties of a petroleum coke, but also in its chemical properties 
[18]. The wettability and the interaction between pitch and bio-coke can also be related to both physical and chemical properties of a bio-coke. Different lignocellulosic materials (carbon precursor) used for producing biocokes and the method of production are the determining factors for the physical and chemical properties of biocokes [35].

\subsection{Physical characterization of bio-cokes}

\subsubsection{Pitch/bio-coke interactions}

The optical microscopy images on a surface across of a pitch drop and bio-coke substrate in the sessile-drop system are shown in Figure 4. The pitch and bio-coke particles can be easily identified from these images (see for example Figure 4 (c and d)). It can be observed that pitch can penetrate into the cell lumen structure of biocoke (pores) (see Figure 4 (c)); however, the particles present in pitch do not properly penetrate into the cell lumen of bio-coke in longitudinal direction (see Figure 4 (d)). This indicates that the porosity in bio-cokes play an important role in their wettability by pitch.

\subsubsection{Characterization by SEM}

SEM micrographs illustrating the appearance of uncalcined and calcined bio-cokes and the petroleum coke at low magnification $(\sim \times 20)$ are shown in Figure 6 (a-c), respectively. Even at this low magnification, differences in the morphology of particles can be detected. The particles of calcined bio-cokes have more needle or ribbonlike shapes than those before calcinations (shown in Figure 6 (a and b)). This indicates that the high temperature calcination process can improve the bio-coke structure since it seems to become more anisotropic. This is in agreement with the results reported by Rocha and his co-workers [18]. They found that the bio-coke obtained by high-temperature treatment at $450^{\circ} \mathrm{C}$ and $500^{\circ} \mathrm{C}$ are completely anisotropic. The petroleum coke particles shown in Figure 6 (c) display the shape pattern between those of bio-coke and shot coke [17]. Shot coke [36] is defined as the coke with an isotropic form and a unique structure. As stated above, it can be concluded that the structures of bio-cokes after calcination seemed to be more similar to that of petroleum coke. The SEM analysis confirmed the anisotropic structure of bio-cokes.

Figure 6 (d-f) shows the SEM images of the structures of investigated bio-coke- 2 and petroleum coke samples on the longitudinal surface at high magnification $(\times 2000)$. From Figure $6(\mathrm{~d}$ and e), it can be observed that the microstructure morphology of uncalcined bio-coke-2 and calcined bio-coke-2 present similar. The structural units found in cokes are generally classified as flat, lamellar, intermediate, and granular [37]. The term intermediate carbon is used to describe carbon components which have either small distorted lamellae or elongated grains [37]. The micrograph in Figure 6 (f) illustrates lamellar components on the surface of the petroleum coke used. The appearance of delicately corrugated lamellae in Figure 6 (f) seems to be similar to the well-defined lamellar components in a particle of good quality needle-coke of a study reported in the literature [37]. The longitudinal surfaces of three uncalcined and calcined bio-cokes (Figure 6(d-e)) look similar to that of the petroleum coke, showing corrugated lamellae. The surfaces of calcined bio-cokes have structures closer to those of petroleum coke, supporting the result obtained from the low magnification SEM micrographs. It was reported in the literature that coke containing low proportions of intermediate carbon produced anodes of higher strength [37]. Bio-coke seems to have a suitable structure for use in anode production according to the wettability and the structural study results. However, there are other properties that need to be tested such as chemical compatibility with pitches, mechanical and electrical properties, etc. in order to determine its potential as anode raw material. The examination of transverse surfaces of bio-cokes gives complementary information. Pore structures can be seen clearly in Figure 6 ( $g$ and $\mathrm{h}$ ). The average pore diameter of calcined bio-coke (Figure 6 (h)) seems to be smaller than those of bio-coke before calcination (Figure 6 (g)). This might be one of the reasons for the reduction observed in the contact angles and the K-values of bio-cokes after calcination (see Figure 2 and Figure 5). Figure 6 (i) displays the dendritic micro-cracks on the surface of the petroleum coke sample. The high level of open porosity of bio-coke might mean that pitch could fill the pores and carbonize during baking, consequently, interlock and bond the structure together if the level of wettability of bio-coke by pitch is suitable. As can be seen from Figure 3, which shows the penetration of pitch across the surface of the droplet on a bio-coke bed, pitch does not properly penetrate in the longitudinal direction of the cell lumen of bio-coke. The highly porous structure of bio-coke might result in low anode density and high amount of pitch utilization, which are disadvantageous. Porous bio-coke will need extra pitch as it will likely penetrate deep into the pores. Carbonized pitch has a lower strength than the coke itself. Therefore, too much pitch is not appropriate. This can again influence the strength of the coke-pitch bond and final anode properties [38]. In addition, increase in the pitch utilization will increase the cost due to its higher price compared to coke. Monsen and his co-workers suggested that the fine particles of bio-coke should be used to break down the porous structure to enhance the density of bio-coke particles for utilization in carbon anode production [12].

The structures and morphologies of six bio-cokes from different biomass origins and with different manufacturing processes were investigated and compared with those of one petroleum coke. SEM images for all 
bio-coke samples indicate anisotropic and lamellar structure similar to that of petroleum coke, and this type of structure is considered suitable for utilization in carbon anode production. However, whether or not the pitch will enter the pores depends on the wettability of bio-coke by pitch to be used. Even if the pitch enters the pores, the pitch utilization will increase accompanied by likely decrease in mechanical properties. Therefore, it is suggested that the bio-coke is used in fine fraction of the anode raw material to decrease the effect of its porosity. Bio-cokes seem to have a suitable structure as anode raw materials provided that the other anode properties are also appropriate and the bio-coke is used to replace one part of the fine fraction in anode recipe. Structural difference in different biomass materials might results in different structure of bio-cokes. The calcination process seems to modify the bio-coke structure towards more anisotropic.

SEM images show that there are differences in texture and porosity of the coke samples. It is difficult to correlate this textural information to wetting but the porosity information may help explain the differences in wettability. Bio-coke samples show high porosity compared to that of petroleum coke sample. Thus, pitch can penetrate easily in bio-coke sample. This trend can be seen in the contact angle results (see Figure 3). If the SEM images of calcined and uncalcined bio-cokes are compared, it is difficult to conclude anything because they show similar amount of porosity. Thus, the difference between the calcined and uncalcined bio-coke may be explained based on their chemical nature.

\subsection{Chemical characterization of bio-cokes}

The XPS technique covers the subsurface to a depth of about 1-20 nm and provides information on the chemical states, surface chemical composition as well as the position of different types of atoms [31, 33]. In this study, differences in surface chemistry of bio-cokes before and after calcination were investigated using XPS spectroscopy and FTIR in order to study the effect of heat treatment conditions and the utilization of different biomass sources on the bio-coke composition, and subsequently on the wettability of bio-coke by pitch. It should be mentioned that although both XPS and FTIR are techniques which are used to determine surface chemistry, each technique has its strengths and weaknesses. The penetration depth of XPS is less than that of FTIR, which is typically between 0.5 and $2 \mu \mathrm{m}$ [39]. Thus, XPS is more of a surface-sensitive technique than FTIR. However, FTIR can identify the existing functional groups, and this information is required as input for the deconvolution of peaks obtained by XPS. Therefore, they are complimentary.

\subsubsection{Characterization using FTIR spectroscopy}

The surface functional groups of the petroleum coke, bio-cokes before and after calcination as well as those of the coal tar pitch were identified by FTIR. Each sample was tested two or three times, and the average of these spectra of the sample were used for spectrum analysis. It was reported that the calcined petroleum coke has very low transmission characteristics to baseline levels [43]. There are some characteristic peaks found in different green petroleum cokes. The most representative bands for the green petroleum coke and pitch within the spectral range of 4000-400 cm-1 are summarized in Table 3, respectively. The FTIR spectra of pitch at room temperature and three calcined cokes are shown in Figure 7 (a) and (b). Figure 7 (c) shows the FTIR spectra in the spectral region of $4000-400 \mathrm{~cm}-1$ on different bio-coke samples. Differences due to the manufacturing process of bio-cokes can be clearly seen in the band shapes of the spectrum.

Polycyclic aromatic hydrocarbons (PAH) are predominant in pitch. Alkylated PAH, cyclopenteno moieties partially hydrogenated PAH, oligo-aryl methanes, hetero-substituted PAH: NH2, OH, carbonyl derivatives of $\mathrm{PAH}$, polycyclic heteroaromatic compounds are also found in pitch [44, 45]. The FTIR analysis of pitch (Figure 7 (a)) was carried out separately at room temperature. Pitch displays a broad peak around $3400 \mathrm{~cm}-1$ for amines (NH) or OH groups. Around $3109 \mathrm{~cm}-1$, a peak is observed due to aromatic $\mathrm{CH}$ stretching vibrations. Another peak is observed at around $2904 \mathrm{~cm}-1$ due to aliphatic $\mathrm{CH}$ stretching vibrations on pitch surfaces. A weak peak at $1725 \mathrm{~cm}-1$ was noticed due to carbonyl group $(\mathrm{C}=\mathrm{O})$. Multiple peaks were detected around $1050 \mathrm{~cm}-1$, which are due C-O stretching of acid/alcohol/ether/ester. Various bands related to aromatic $\mathrm{CH}$ out-of-plane bending with different degrees of substitution are observed in the region of 700-900 cm-1. A very sharp peak at $853 \mathrm{~cm}-$ 1 is detected due to substituted aromatic ring vibrations. There is a possibility that the functional groups in the coal tar pitch may interact with those complimentary functional groups present on the bio-coke surface. Therefore, in addition to the physical and structural aspects (such as porosity of coke), the functional groups such as amines (-NH), hydroxyl groups $(-\mathrm{OH})$, carboxyl groups $(-\mathrm{COOH})$, carbonyl groups $(\mathrm{C}=\mathrm{O})$, and $-\mathrm{O}-$ groups in ethers contribute to the affinity for pitch. The changes of these functional groups can change the wettability of pitch. The bands at 3500 3200, 1800, and $1100 \mathrm{~cm}-1$ in Table 4 refer to different heteroatom containing groups such as amines $(-\mathrm{NH})$, hydroxyl groups $(-\mathrm{OH})$, carboxyl groups $(-\mathrm{COOH})$, carbonyl groups $(\mathrm{C}=\mathrm{O})$, and ether (-O-) groups [46, 47].

The FT-IR spectra of bio-cokes after calcination to $1200^{\circ} \mathrm{C}$ show the presence of similar chemical functionalities (see Figure 7 (b)). Thus, it is difficult to see the effect of raw materials on the chemical structure of calcined bio-cokes by the FTIR analysis. It is difficult for FTIR to detect the functional groups which are 
highly symmetrical. The results of bio-cokes pyrolyzed to $426^{\circ} \mathrm{C}$ starting with different raw materials also showed similar to each other with regards to functionality (spectra are not presented here). Thus, it appears that there is no significant effect of raw materials on chemical structure of pyrolyzed bio-coke before calcination.

Figure 7 (c) shows the comparison in FTIR spectra of the uncalcined bio-coke-3 pyrolyzed to $426^{\circ} \mathrm{C}$, bio-coke calcined to $1200^{\circ} \mathrm{C}$, and the petroleum coke. The FTIR spectra are significantly different for bio-cokes before and after calcinations. It can be noted that, the FTIR spectra typically displays a band near $3640 \mathrm{~cm}-1$ related to free moisture or free $\mathrm{OH}$ for bio-coke before calcination, but that peak disappears after calcination. This might be attributable to the removal of small molecules (such as water) during the condensation reaction or to the reaction with the oxygen containing functional groups to form a covalent bond during the calcination process. The water molecules leave the calcined samples during heating. Thus, the amount of free $\mathrm{OH}$ reduces significantly. It is found that there are significant differences at $3450 \mathrm{~cm}-1$ and $3320 \mathrm{~cm}-1$ between bio-cokes before and after calcination. A doublet peak can be detected at 3450-3320 cm-1 in bio-coke before calcination, while no band can be found in the bio-coke after calcination. This is attributable to loss of $\mathrm{O} / \mathrm{N}$ or structural change of the molecules of bio-coke during the calcination process. The band at $3450 \mathrm{~cm}-1$ represents carboxyl groups (-COOH), and the band at $3320 \mathrm{~cm}-1$ refers to amines $(-\mathrm{NH})$ or hydroxyl groups $(-\mathrm{OH})$. These groups can form hydrogen bond or covalent bonds with oxygen or nitrogen containing functional groups in pitch. Compounds with the nitrogen atom (free $\mathrm{NH}$ ) in bio-cokes might attach to a carbonyl structure of pitch to form amides or hydrogen bonds. Therefore, their presence is desirable to increase the wettability of pitch on bio-coke surface. The FTIR spectra for bio-coke before calcination consist of a band near $3111 \mathrm{~cm}-1$ due to aromatic C-H stretching vibrations. Presence of both aromatic rings and - $\mathrm{OH}$ groups indicates likely the presence of phenols which are acidic in nature. This acidic group in the bio-coke could react with the basic amine (-NH2) groups of pitch. Therefore, their presence is helpful for the wetting by pitch. A band at $2890 \mathrm{~cm}-1$ corresponding to saturated aliphatic C-H stretching vibrations of alkyl substituents and methylene groups in hydro aromatic compounds is observed for bio-coke before calcinations but not for the ones after calcination. As shown in Figure 7 (c), the characteristic bands of aliphatic C-H decrease significantly as a result of the calcination process. It indicates that the availability of aliphatic $\mathrm{C}-\mathrm{H}$ groups are reduced due to the condensation, rearrangement, and cyclization reactions during calcination, and this results in the presence of smaller chains of aliphatic hydrocarbons compared to those in bio-coke before calcination. It can be observed that the intensity of the band at $1640 \mathrm{~cm}-1$ is significantly higher in bio-coke before calcination than that after calcinations. This band refers to carbonyl group $(\mathrm{C}=\mathrm{O})$ in quinines and quinine methides [48] or adsorbed water [49]. The group can form covalent bonds and assist hydrogen bonding with the hydrogen atoms attached to oxygen or nitrogen atoms of functional groups in pitch, consequently resulting in good wettability. It can be seen that the band at $1510 \mathrm{~cm}-1$ which is assigned to aromatic $\mathrm{C}=\mathrm{C}$ bond in lignin disappears after calcination. This peak is usually weak/medium for aromatic compounds. It is also possible that some of the aromatic rings rearrange themselves and lose their aromaticity. Carbonyl $(\mathrm{C}=\mathrm{O})$ and $\mathrm{C}=\mathrm{C}$ bond stretching exhibit bands close to each other; thus, they are sometimes difficult to assign because of the overlap with each other. The double bonds contain a $\square$ bond, which is not as strong as the sigma bonds and therefore is easy to decompose. $\mathrm{C}=\mathrm{C}$ bond stretching in aromatic compounds helps wetting by forming electrostatic bonds. The intensity at $1431 \mathrm{~cm}-1$ corresponding to the $\mathrm{C}=\mathrm{C}$ stretching or bending vibrations of methyl groups for bio-cokes are stronger in the case of uncalcined bio-cokes compared to calcined ones. The peak at around $871 \mathrm{~cm}-1$ represents a substitution reaction in the aromatic ring. Thus, it may be assumed that most of the methyl groups are present in long chains and attached to the aromatic rings as side chains. Aliphatic chains in $\alpha$-positions can easily undergo cyclization [43] during calcination and interact with pitch. The ortho-substitution of the aromatic rings was found at the $871 \mathrm{~cm}-1 \mathrm{band}$ for bio-coke before calcination; however, this is not significantly present in bio-coke after calcination. This reduction of peak at $871 \mathrm{~cm}-1$ after calcination shows that the aliphatic chains of substituted aromatic rings lead to condensation or cyclization during calcination (by intra and inter molecular bond). In addition, C-O stretching of aliphatic or aromatic acid/alcohol/ether or ester appears approximately at $1150 \mathrm{~cm}-1$ for bio-coke before calcination.

The differences in the spectra of bio-coke and petroleum coke have to be taken into consideration. Upon analysis of the spectra, the results show that the surface chemical composition of bio-cokes both before and after calcination are very different in nature compared to that of the petroleum coke studied. It was reported that petroleum cokes are composed of poly-nuclear aromatic hydrogen-deficient structures with few alkyl side chains as substituents and naphthenic groups such as naphthalene, phenanthrene, anthracene, tri-phenylene, benzo-pyrene, coronene, pyrene, etc. [50]. This is in agreement with the FTIR result of the current work. It was mentioned that the surface functional groups such as $\mathrm{C}-\mathrm{OH}, \mathrm{COOH}$, and some alkyl groups of petroleum cokes play a key role in the chemical activation process [18]. As can be seen in Table 3, all the bands at 3500 3200, 1800 , and $1100 \mathrm{~cm}-1$ referring to heteroatoms containing groups such as amines (-NH), hydroxyl groups (-OH), carboxyl groups $(-\mathrm{COOH})$, carbonyl group $(\mathrm{C}=\mathrm{O})$, and $\mathrm{C}-\mathrm{O}$ groups help improve the wetting of coke surface by pitch. As shown in Figure 7 (c), all these characteristic bands are stronger for uncalcined bio-coke than that for 
petroleum coke. These results might explain the reason for the better wettability of bio-cokes by pitch compared to that of the petroleum coke (see Figure 2).

Table 4 shows the functional groups found in different bio-cokes, petroleum coke, and pitch. ' + ' in columns \#1, \#4, and/or \#6 implies more possibilities of chemical interaction by hydrogen bonding, covalent bonding, and condensation reactions, thus, leading to an increase in wettability of coke by pitch. '+' in column \#2 indicates the presence of aromatic rings which have negatively charged $\square$ electron cloud. These form electrostatic bonding with the electron-deficient centers. Consequently, in the presence of groups such as NR4+, this also improves wetting. Calcined bio-cokes do not contain significant amount of nitrogen; therefore, the presence of aromatic rings does not facilitate wetting. ' +' in column \#3 and \# 7 indicates the presence of aliphatic chains and branches to aromatic rings. Free aliphatic chains usually inhibit wetting as they can offer steric hindrance to other reacting molecules. Branches sometimes might help in condensation and cyclization reactions. Cyclization reactions are usually important during calcination as it increases carbon to hydrogen ratio.

The FITR spectrum of calcined bio-coke does not show sharp peaks for OH/NH/COOH, but XPS study shows their presence. It is possible that the FTIR peak is highly diffused in nature due to interactions between the $\mathrm{OH} / \mathrm{NH} / \mathrm{COOH}$ attached to different molecular-weight compounds. During calcination, different bonds can break and/or rearrange and produce compounds of various molecular weights.

\subsubsection{Characterization using XPS spectroscopy}

A typical XPS survey spectrum of uncalcined bio-coke-3 is shown in Figure 8 (a). The spectra of this bio-coke reveal the presence of carbon, oxygen, and small amounts of nitrogen as expected. In this analysis, the focus was on the resolution of the C1s peak since it is the major element found to be present.

To evaluate the chemical structures of the bio-cokes, high-resolution XPS spectra of C 1s levels were deconvoluted. All of the $\mathrm{C}$ ls spectra were found to be consisted of components which have carbon-containing functional groups. The composition of the high-resolution spectra of $\mathrm{C}$ 1s was fitted to five components [28]. The five peaks in the deconvoluted high-resolution XPS spectrum of the $\mathrm{C} 1 \mathrm{~s}$ peaks are expressed as $\mathrm{C}_{1}-\mathrm{C}_{5}$, and these carbon bands correspond to $\mathrm{C}_{1}(\mathrm{C}=\mathrm{C}), \mathrm{C}_{2}(\mathrm{C}-\mathrm{C}), \mathrm{C}_{3}(\mathrm{C}-\mathrm{N} / \mathrm{C}-\mathrm{O} / \mathrm{C}-\mathrm{S}), \mathrm{C}_{4}\left(\mathrm{C}=\mathrm{O} / \mathrm{CSO}_{2}\right)$, and $\mathrm{C}_{5}(\mathrm{COOH})$, respectively, as shown in Table 5 . The different functional groups were chosen based on the FTIR data and information from literature [28]. The curve fitting of the C 1s envelope was also performed resolving the contributions of different groups. The high-resolution XPS spectra of C 1s for bio-coke-3 before and after calcination were detected and shown in Figure 8 (b-c). A careful analysis of the general line shapes and intensities of each component shows similar XPS patterns for bio-coke-1 and bio-coke-2 before calcination so they are not presented here. However, the XPS patterns changed considerably due to calcination for all three bio-cokes. All five peaks are modified by the calcination process. The contribution of $\mathrm{C}_{1}$ and $\mathrm{C}_{2}$ peaks are more than those of $C_{3}, C_{4}$, and $C_{5}$ peaks for samples before calcination (Figure 8 (b)). This indicates that the uncalcined bio-coke has higher $\mathrm{C}_{1}$ and $\mathrm{C}_{2}$ concentrations. The most important contributions before and after calcination come from the $\mathrm{C}_{1}$ class (see Table 5). In other words, it appears that the $\mathrm{C}_{1}$ class is most abundant in bio-cokes. However, as can be seen from the comparison of the $\mathrm{C}$ 1s spectral parameters of bio-coke samples before and after calcination (see Table 5), $C_{3}$ and $C_{4}$ peaks changed most significantly due to calcination. The $\mathrm{C}_{3}, \mathrm{C}_{4}$, and $\mathrm{C}_{5}$ class peaks decrease while both $\mathrm{C}_{1}$ and $\mathrm{C}_{2}$ class peaks increase due to calcination for all three bio-cokes. $\mathrm{C}_{3}$ class contains oxygen and/or nitrogen bonds. Calcined bio-cokes contain more $\mathrm{C}=\mathrm{C}$ bonds $\left(\mathrm{C}_{1}\right.$ class) than those before calcination except calcined bio-coke-3, which shows slight lower value than that before calcinations (see Table 5). The double bonds contain both sigma and pi bonds; consequently, they are more reactive. Pi bonds are not as strong as sigma bonds; therefore, they are easier to break. Usually the pi electron cloud of aromatic compounds facilitates wetting by forming electrostatic bond with electron deficient centers such as quaternary ammonium or substituted ammonium functional group. Atomic percentages of different elements of the coal tar pitch sample are also presented in Table 5. Since the pitch sample has a negligible quantity of $\mathrm{N}$, positive center compounds are not present in notable quantity in the coal tar pitch. Thus, the higher amount of $\mathrm{C}=\mathrm{C}$ in calcined bio-cokes do not affect the wettability. The XPS results are in agreement with the wettability test results as explained below. Lower $\mathrm{N}$ concentration in calcined bio-cokes can be attributed to the presence of lower concentration of amine (C-N) groups. As XPS mainly analyzes surface functional groups, a zero percent nitrogen does not ensure that there is no nitrogen compound present in the sample. Also due to the detection limit of the equipment, an element present in a very small quantity on the surface may not be detected. Thus, the zero percentage of nitrogen in calcined coke might indicate the presence of a very small quantity of nitrogen-containing functional groups. The lack of $\mathrm{N}$ might be the reason for decreased wettability (higher contact angles) of calcined bio-coke compared to that of uncalcined bio-coke by pitches. CN and/or C-O functional groups ( $\mathrm{C}_{3}$ class) and $\mathrm{C}=\mathrm{O}$ ( $\mathrm{C}_{4}$ class) of all bio-cokes can form covalent bonds or hydrogen bond with the complementary functional groups present in pitch; therefore, their presence might results in better wetting. The reduction of these two classes after the calcination of bio-coke reduces the chances of any chemical reaction taking place and thereby might decrease the wettability of coke by pitch (Figure 2). Also, the presence of $\mathrm{COOH}$ 
( $\mathrm{C}_{5}$ class) might play a key role in chemical reactions with pitch during mixing. $\mathrm{COOH}$ contributes to reactions not only through the formation of hydrogen bonds, but also through acid-base (such as reaction with amine molecules) reactions. Bio-cokes contain $\mathrm{COOH}$ functional groups ( $\mathrm{C}_{5}$ class) before calcination; however, they disappear after calcination. Therefore, it is possible that calcined bio-cokes were able to form fewer chemical bonds with pitch compared to uncalcined bio-cokes.

Increase in the presence of $\mathrm{O}, \mathrm{N}$, and $\mathrm{S}$ and functional groups such as $\mathrm{CN} / \mathrm{CO} / \mathrm{CS}, \mathrm{C}=\mathrm{O}$, and $\mathrm{COOH}$ increases wetting. From the analysis stated before and the results found in Table 5, it can be concluded that the presence of $\mathrm{C}=\mathrm{C}$ in high quantity can help form electrostatic bonds with electron deficient centers such as $\mathrm{NR}_{4}^{+}$(where $\mathrm{R}$ stands for hydrogen, alkyl or aryl groups) which facilitates wetting. Calcined bio-cokes do not contain significant amounts of nitrogen, thus, the presence of aromatic rings does not influence the wetting. Due to their high electronegativity, the heteroatoms $(\mathrm{O}, \mathrm{N}$, and $\mathrm{S}$ ) facilitate the formation of hydrogen bonds with the hydrogen atom connected to other heteroatoms. As calcined bio-cokes have less hetero atoms than the corresponding uncalcined bio-cokes, they are wetted less by the pitch. The XPS spectrum of pitch shows that it contains high amount of oxygen (heteroatoms), which facilitates the reaction with bio-cokes containing more heteroatoms. Thus, pitch can wet the uncalcined bio-cokes more than the calcined ones. When the wettability of calcined bio-cokes is compared with those of petroleum coke, it can be observed that calcined bio-cokes contain more heteroatoms. Thus, this might be one of the reasons that pitch can wet calcined bio-cokes more than the petroleum coke. All bio-cokes also contain a high amount of oxygen compared to the petroleum coke. Therefore, pitch wets all bio-cokes better than it wets the petroleum coke bed. This is in agreement with the wettability test results.

The deconvolution of the C1s peak shows different information but it was observed that it can only explain the difference in wettability between the calcined and the uncalcined samples.

A district trend was observed using $\mathrm{O} / \mathrm{C}$ ratio (Figure 5). It has been previously reported that the degradation of cellulosic materials and polymers can be detected by a change in the $\mathrm{O} / \mathrm{C}$ atomic ratio [40]. The O/C atomic ratio is almost always used in quantitative analysis when XPS is used to characterize biomass surfaces [41]. This ratio can be calculated by using the total areas of peaks of different components and their respective photoemission cross-sections. The effect of oxygen to carbon $(\mathrm{O} / \mathrm{C})$ ratio on the K-value of bio-cokes is shown in Figure 5. For all three bio-cokes, the K-value decreases as the $\mathrm{O} / \mathrm{C}$ ratio decreases due to calcination. This indicates that the $\mathrm{O} / \mathrm{C}$ ratio decreases as a result of calcination, which, in turn, can reduce bio-coke wettability by pitch. Tang and Roger Bacon [42] provided the breakdown of each of the cellulosic ring units that takes place around $400^{\circ} \mathrm{C}$ and results in formation of carbon intermediates containing four carbon atoms. It was also found that the carbon atom intermediates were re-polymerized to form a condensed aromatic system and subsequently a graphitic structure within the temperature range of $370-700^{\circ} \mathrm{C}$. The formation of a condensed aromatic system decreases the $\mathrm{O} / \mathrm{C}$ ratio of bio-coke. This might explain the decrease in $\mathrm{O} / \mathrm{C}$ ratio of bio-coke after calcination. The greater the percentage of hetero atoms $(\mathrm{O}, \mathrm{N}, \mathrm{S})$ is, the higher the possibility is for forming bonds between bio-coke and pitch functional groups; consequently, the wettability decreases with decreasing percentage of heteroatoms. The decrease in $\mathrm{O} / \mathrm{C}$ ratio explains the decrease of wettability of bio-coke after calcination (see Figures 1 and 2). The O/C ratio for bio-cokes before and after calcination is proportional to their K-values as shown in Figure 5. This indicates that the different biomass raw materials have significant effect on the $\mathrm{O} / \mathrm{C}$ ratio and the $\mathrm{K}$-value of bio-cokes before and after calcination.

It can be clearly seen that $\mathrm{O} / \mathrm{C}$ ratio is a very important criteria that can describe the trend of wettability between structural similar samples, when structural different samples are compared porosity measurement became another important part.

FTIR and XPS results are complementary to each other. FTIR shows the presence of functional groups in the bulk of the material. XPS gives information about the surface functional groups. Usually the functional groups present in FTIR can be identified by XPS but the sensitifity of the XPS equipment sometimes impose limitations. In all the uncalcined samples, distinct peaks were observed at the wavenumbers descriver in Table 3. For the calcined samples it was difficult to identify the peaks. Similar problem has been reported for calcined petroleum coke by different researchers (). XPS proved to be an important tool for analyzing the surface functional groups of calcined bio-coke samples.

\section{Conclusions}

In this project, the effects raw material source and the manufacturing process on the bio-coke properties were studied using different methods. From the experimental results obtained and their analyses, the following conclusions can be drawn.

Bio-cokes (before and after calcination) are better wetted by pitch than petroleum coke; therefore, they might be considered suitable for carbon anode production for use in aluminum electrolysis from the wettability point of 
view. Changes in wettability during calcination differ according to the origin of biomass materials and are likely due to combination of structural and chemical properties of the bio-cokes.

Bio-coke samples present anisotropic and lamellar structure similar to that of petroleum coke (which is considered suitable for anode production) from the structural point of view. Structural differences in different biomass materials might result in different bio-cokes structures. The calcination process makes the bio-coke structure more anisotropic. The high level of porosity of bio-cokes allows the penetration of pitch into the particle and bond the structure together during carbonization. However, coke with porosity above a certain level is not suitable for anode production. Therefore, the utilization of bio-coke for replacing one part of the fine fraction in anode recipe is recommended.

XPS results show that $\mathrm{C}=\mathrm{C}$ and $\mathrm{C}-\mathrm{C}$ groups increase while $\mathrm{C}-\mathrm{N} / \mathrm{C}-\mathrm{O} / \mathrm{C}-\mathrm{S}$ groups, $\mathrm{C}=\mathrm{O} / \mathrm{CSO}_{2}$ groups, and $\mathrm{COOH}$ groups decrease due to calcination for all three bio-cokes. FTIR results show that the surfaces of biocokes are quite different in chemical nature compared to that of the petroleum coke studied.

\section{Acknowledgements}

Authors thank the Natural Sciences and Engineering Research Council of Canada (NSERC) for the financial support, their industrial partner Boisaco for the technical and financial contributions, and the University Research Centre on Aluminum (CURAL) for the technical support during the SEM tests. We also thank the Alberta Centre for Surface Engineering and Science (ACSES) of the University of Alberta for the technical support during the XPS analysis.

\section{References}

[1] A.R. Coutinho, J.D. Rocha, C.A. Luengo, Preparing and characterizing biocarbon electrodes, Fuel processing technology, 67 (2000) 93-102.

[2] K.L. Hulse, Anode Manufacture, in, R\&D Carbon Ltd., New Zealand, 2000.

[3] J.M. Burgess, Biomass and renewables as alternative energy sources and reductants in the minerals industry, in, Fremantle, 2004, pp. 9-13.

[4] R.-L. Tseng, S.-K. Tseng, F.-C. Wu, Preparation of high surface area carbons from Corncob with KOH etching plus CO2 gasification for the adsorption of dyes and phenols from water, Colloids and Surfaces A: Physicochemical and Engineering Aspects, 279 (2006) 69-78.

[5] F.-C. Wu, R.-L. Tseng, Preparation of highly porous carbon from fir wood by KOH etching and CO2 gasification for adsorption of dyes and phenols from water, Journal of Colloid and Interface Science, 294 (2006) 21-30.

[6] B.S. Girgis, A.A. Attia, N.A. Fathy, Modification in adsorption characteristics of activated carbon produced by H3PO4 under flowing gases, Colloids and Surfaces A: Physicochemical and Engineering Aspects, 299 (2007) 79-87.

[7] R.-L. Tseng, S.-K. Tseng, Characterization and use of high surface area activated carbons prepared from cane pith for liquid-phase adsorption, Journal of Hazardous Materials, 136 (2006) 671-680.

[8] Y.-J. Kim, B.-J. Lee, H. Suezaki, T. Chino, Y. Abe, T. Yanagiura, K.C. Park, M. Endo, Preparation and characterization of bamboo-based activated carbons as electrode materials for electric double layer capacitors, Carbon, 44 (2006) 1592-1595.

[9] J.D. Rocha, A.R. Coutinho, C.A. Luengo, Biopitch produced from eucalyptus wood pyrolysis liquids as a renewable binder for carbon electrode manufacture, Brazilian Journal of Chemical Engineering, 19 (2002) 127-132.

[10] A.K. Kercher, D.C. Nagle, Microstructural evolution during charcoal carbonization by X-ray diffraction analysis, Carbon, 41 (2003) 15-27.

[11] M.J. Antal Jr, M. Grønli, The art, science, and technology of charcoal production, Industrial and Engineering Chemistry Research, 42 (2003) 1619-1640.

[12] B.E. Monsen, A.P. Ratvik, L.P. Lossius, Charcoal in anodes for aluminium production, in, Seattle, WA, 2010, pp. 929-934.

[13] C. Avila, C.H. Pang, T. Wu, E. Lester, Morphology and reactivity characteristics of char biomass particles, Bioresource Technology, 102 (2011) 5237-5243.

[14] M.J. Wornat, R.H. Hurt, N.Y.C. Yang, T.J. Headley, Structural and compositional transformations of biomass chars during combustion, Combustion and Flame, 100 (1995) 131-143.

[15] F.G. Emmerich, J.C. de Sousa, I.L. Torriani, C.A. Luengo, Applications of a granular model and percolation theory to the electrical resistivity of heat treated endocarp of babassu nut, Carbon, 25 (1987) 417-424.

[16] K. Mochidzuki, F. Soutric, K. Tadokoro, M.J. Antal Jr, M. Tóth, B. Zelei, G. Várhegyi, Electrical and physical properties of carbonized charcoals, Industrial and Engineering Chemistry Research, 42 (2003) 5140-5151. 
[17] X. Huang, D. Kocaefe, D. Bhattacharyay, Y. Kocaefe, Morphological and Microstructural Characterization of Bio-coke as Potential Anode Raw Material for Aluminum Industry, in: Materials Science \& Technology 2013, Montreal, Canada, 2013.

[18] V.G. Rocha, C. Blanco, R. Santamaría, E.I. Diestre, R. Menéndez, M. Granda, An insight into pitch/substrate wetting behaviour. The effect of the substrate processing temperature on pitch wetting capacity, Fuel, 86 (2007) 1046-1052.

[19] E.A. Heintz, Wetting of filler by binder- A simple apparatus for determining wetting temperatures, in, American Carbon Soc, Lexington, KY, USA, 1985, pp. 320-321.

[20] J. Lahaye, P. Ehrburger, Pitch-coke interactions, Fuel, 64 (1985) 1187-1191.

[21] P. Couderc, P. Hyvernat, J.L. Lemarchand, Correlations between ability of pitch to penetrate coke and the physical characteristics of prebaked anodes for the aluminium industry, Fuel, 65 (1986) 281-287.

[22] J. Cao, A.N. Buckley, A. Tomsett, Re-examining the pitch/coke wetting and penetration test, JOM, 54 (2002) 30-33.

[23] N.A. Adams, Characterization on Pitch Wetting and Penetration Behaviour of Petroleum Coke and Recycled Butts in Prebake Carbon Anode, (2004).

[24] V.G. Rocha, C. Blanco, R. Santamaría, E.I. Diestre, R. Menéndez, M. Granda, Pitch/coke wetting behaviour, Fuel, 84 (2005) 1550-1556.

[25] N.Y. Beilina, E.L. Mizitov, I.A. Bubnenkov, Effect of the nature and degree of anisotropy of cokes on their interaction with coal-tar pitch and its components, Solid Fuel Chemistry, 40 (2007) 44-49.

[26] B. Petrova, T. Budinova, E. Ekinci, N. Petrov, F. Yardim, Influence of pitch composition and surface properties of petroleum coke on their interaction during the preparation of carbon/carbon composites, Carbon, 45 (2007) 704-709.

[27] V.G. Rocha, C. Blanco, R. Santamaría, E.I. Diestre, R. Menéndez, M. Granda, The effect of the substrate on pitch wetting behaviour, Fuel Processing Technology, 91 (2010) 1373-1377.

[28] A. Sarkar, D. Kocaefe, Y. Kocaefe, D. Sarkar, D. Bhattacharyay, B. Morais, J. Chabot, Coke-pitch interactions during anode preparation, Fuel, 117 (2014) 598-607.

[29] S.Q. Shi, D.J. Gardner, Dynamic adhesive wettability of wood, Wood Fiber Sci, 33 (2001) 58-68.

[30] X. Huang, D. Kocaefe, Y. Boluk, Y. Kocaefe, A. Pichette, Effect of surface preparation on the wettability of heat-treated jack pine wood surface by different liquids, European Journal of Wood and Wood Products, 70 (2012) 711-717.

[31] G. Sinn, A. Reiterer, S.E. Stanzl-Tschegg, Surface analysis of different wood species using X-ray photoelectron spectroscopy (XPS), Journal of Materials Science, 36 (2001) 4673-4680.

[32] G. Nguila Inari, M. Petrissans, J. Lambert, J.J. Ehrhardt, P. Geİ $\square$ rardin, XPS characterization of wood chemical composition after heat-treatment, Surface and Interface Analysis, 38 (2006) 1336-1342.

[33] D.N.S. Hon, ESCA study of oxidized wood surfaces, Journal of Applied Polymer Science, 29 (1984) 27772784.

[34] J. Shore, Wood, The Antioch Review, 45 (1987) 66-67.

[35] M. Olivares-Marín, C. Fernández-González, A. Macías-García, V. Gómez-Serrano, Preparation of activated carbon from cherry stones by chemical activation with ZnCl2, Applied Surface Science, 252 (2006) 59675971.

[36] P.J. Ellis, J.D. Bacha, Shot coke, in: Y. Lin Ray, Y.A. Chang, G. Reddy Ramana, C.T. Liu (Eds.), Anaheim, CA, USA, 1996, pp. 477-484.

[37] D. Hays, J.W. Patrick, A. Walker, SEM characterization of cokes and carbons, in: Fuel, 1983, pp. 10791083.

[38] C.-L. Bergeron-Lagacé, Réactivité de l'anode et désulfuration : effet du niveau de calcination du coke, in, Universite du Quebec a Chicoutimi, Chicoutimi, 2012, pp. 32.

[39] J. F. M. Mirabella, Practical Spectroscopy Series: Internal Reflection Spectroscopy: Theory and Applications, Marcel Dekker, Inc., New York, 1993.

[40] G. Nguila Inari, M. Petrissans, J. Lambert, J.J. Ehrhardt, P. Gérardin, XPS characterization of wood chemical composition after heat-treatment, Surface and Interface Analysis, 38 (2006) 1336-1342.

[41] Q. Shen, P. Mikkola, J.B. Rosenholm, Quantitative characterization of the subsurface acid-base properties of wood by XPS and Fowkes theory, Colloids and Surfaces A: Physicochemical and Engineering Aspects, 145 (1998) 235-241.

[42] M.M. Tang, R. Bacon, Carbonization of cellulose fibers-I. Low temperature pyrolysis, Carbon, 2 (1964) 211-220.

[43] J.A. Menéndez, J.J. Pis, R. Alvarez, C. Barriocanal, E. Fuente, M.A. Díez, Characterization of petroleum coke as an additive in metallurgical cokemaking. Modification of thermoplastic properties of coal, Energy and Fuels, 10 (1996) 1262-1268.

[44] S.H. Lee, C.S. Choi, Chemical activation of high sulfur petroleum cokes by alkali metal compounds, Fuel processing technology, 64 (2000) 141-153. 
[45] A.N. Adams, H.H. Schobert, Characterization of the surface properties of anode raw materials, in: A.T. Tabereaux (Ed.), Carlotte, NC, 2004, pp. 495-498.

[46] L. Tolvaj, O. Faix, Artificial ageing of wood monitored by DRIFT spectroscopy and CIE L*a*b* color measurements, Holzforschung, 49 (1995) 397-404.

[47] M. Kishino, T. Nakano, Artificial weathering of tropical woods. Part 1: Changes in wettability, Holzforschung, 58 (2004) 552-557.

[48] A. Temiz, N. Terziev, M. Eikenes, J. Hafren, Effect of accelerated weathering on surface chemistry of modified wood, Applied Surface Science, 253 (2007) 5355-5362.

[49] R.A. Kotilainen, T.J. Toivanen, R.J. Alén, FTIR monitoring of chemical changes in softwood during heating, Journal of Wood Chemistry and Technology, 20 (2000) 307-320.

[50] M. Malekshahian, J. Hill, Chemical and thermal modification of petroleum coke, in, Montreal, QC, 2009.

[51] R.I.R. Blyth, H. Buqa, F.P. Netzer, M.G. Ramsey, J.O. Besenhard, M. Winter, X-ray photoemission studies of surface pre-treated graphite electrodes, Journal of Power Sources, 97-98 (2001) 171-173.

[52] M.D. Guillén, M.J. Iglesias, A. Domínguez, C.G. Blanco, Semiquantitative FTIR analysis of a coal tar pitch and its extracts and residues in several organic solvents, Energy \& Fuels, 6 (1992) 518-525.

[53] J. Alcañiz-Monge, D. Cazorla-Amorós, A. Linares-Solano, Characterization of coal tar pitches by thermal analysis, infrared spectroscopy and solvent fractionation, Fuel, 80 (2001) 41-48.

[54] R.I.R. Blyth, H. Buqa, F.P. Netzer, M.G. Ramsey, J.O. Besenhard, P. Golob, M. Winter, XPS studies of graphite electrode materials for lithium ion batteries, Applied Surface Science, 167 (2000) 99-106.

[55] X.l. Zhang, Y. Zhang, F.s. Ding, Q.j. Huang, Y. Li, Effect of the surface properties of an activated coke on its desulphurization performance, Mining Science and Technology, 19 (2009) 769-774. 
Table 1 Materials and pyrolysis and calcination conditions used

\begin{tabular}{|c|c|c|c|c|c|c|}
\hline $\begin{array}{c}\text { Sample } \\
\text { No. }\end{array}$ & $\begin{array}{c}\text { Biocoke } \\
\text { Sample } \\
\text { Tested }\end{array}$ & $\begin{array}{l}\text { Source of } \\
\text { the Sample }\end{array}$ & $\begin{array}{c}\text { Heat } \\
\text { Treatment } \\
\text { Process }\end{array}$ & $\begin{array}{l}\text { Heating } \\
\text { rate } \\
\left({ }^{\circ} \mathrm{C} / \mathrm{min}\right)\end{array}$ & $\begin{array}{l}\text { Holding } \\
\text { Time } \\
\text { (min) }\end{array}$ & $\begin{array}{c}\text { System Used } \\
\text { for Heat } \\
\text { Treatment }\end{array}$ \\
\hline 1 & $\begin{array}{l}\text { Uncalcined } \\
\text { bio-coke-1 }\end{array}$ & Leafy trees & $\begin{array}{c}\text { Pyrolyzed to } \\
426^{\circ} \mathrm{C}\end{array}$ & \multirow{3}{*}{\multicolumn{3}{|c|}{$\begin{array}{l}\text { Directly } \\
\text { received } \\
\text { from } \\
\text { Boisaco }\end{array}$}} \\
\hline 2 & $\begin{array}{l}\text { Uncalcined } \\
\text { bio-coke-2 }\end{array}$ & Softwood & $\begin{array}{c}\text { Pyrolyzed to } \\
426^{\circ} \mathrm{C}\end{array}$ & & & \\
\hline 3 & $\begin{array}{l}\text { Uncalcined } \\
\text { bio-coke-3 }\end{array}$ & Hardwood & $\begin{array}{c}\text { Pyrolyzed to } \\
426^{\circ} \mathrm{C} \\
\end{array}$ & & & \\
\hline 4 & $\begin{array}{c}\text { Calcined } \\
\text { bio-coke-1 }\end{array}$ & $\begin{array}{l}\text { Uncalcined } \\
\text { bio-coke-1 }\end{array}$ & $\begin{array}{l}\text { Calcined to } \\
1200^{\circ} \mathrm{C}\end{array}$ & 40 & 15 & $\begin{array}{l}\text { UQAC-TGA } \\
\text { (induction) }\end{array}$ \\
\hline 5 & $\begin{array}{c}\text { Calcined } \\
\text { bio-coke-2 }\end{array}$ & $\begin{array}{l}\text { Uncalcined } \\
\text { bio-coke-2 }\end{array}$ & $\begin{array}{l}\text { Calcined to } \\
1200^{\circ} \mathrm{C}\end{array}$ & 40 & 15 & $\begin{array}{l}\text { UQAC-TGA } \\
\text { (induction) }\end{array}$ \\
\hline 6 & $\begin{array}{c}\text { Calcined } \\
\text { bio-coke-3 }\end{array}$ & $\begin{array}{l}\text { Uncalcined } \\
\text { bio-coke-3 }\end{array}$ & $\begin{array}{c}\text { Calcined to } \\
1200^{\circ} \mathrm{C}\end{array}$ & 40 & 15 & $\begin{array}{c}\text { UQAC-TGA } \\
\text { (induction) }\end{array}$ \\
\hline 7 & $\begin{array}{c}\text { Petroleum } \\
\text { coke }\end{array}$ & \multicolumn{5}{|c|}{ Industrial petroleum coke already calcined } \\
\hline 8 & Wood chips & \multicolumn{5}{|c|}{ No heat-treatment, for use as reference } \\
\hline
\end{tabular}


Table 2 Summary of initial contact angles (0 s), contact angles at $100 \mathrm{~s}$, and total wetting time (complete submergence of liquid pitch into the substrate) for different bio-cokes and the petroleum coke

\begin{tabular}{ccccc}
\hline & \multicolumn{2}{c}{ Contact angles } & \begin{tabular}{c} 
Percentage \\
decrease in \\
Sontact angle \\
\cline { 2 - 5 }$(\%)$
\end{tabular} & $\begin{array}{c}\text { Total } \\
\text { wetting time } \\
(\mathrm{s})\end{array}$ \\
\cline { 2 - 5 } & $\theta_{\mathrm{i}}\left(^{\circ}\right)$ & $\theta_{100}\left({ }^{\circ}\right)$ & 48.8 & $594.4(1.90)$ \\
\hline Uncalcined bio-coke -1 & $75(0.5)$ & $38(0.8)$ & 50.3 & $339.7(3.13)$ \\
Uncalcined bio-coke -2 & $80(1.0)$ & $40(2.6)$ & 54.3 & $325.5(4.13)$ \\
Uncalcined bio-coke -3 & $64(0.6)$ & $29(0.4)$ & & $>1600$ \\
Calcined bio-coke -1 & $82(0.6)$ & $51(0.6)$ & 37.3 & $490.7(2.50)$ \\
Calcined bio-coke -2 & $97(0.5)$ & $49(2.5)$ & 49.8 & $339.6(2.07)$ \\
Calcined bio-coke -3 & $93(0.6)$ & $43(1.2)$ & 54.2 & $>1600$ \\
Petroleum coke & $86(1.5)$ & $56(2.6)$ & 34.1 & \\
\hline
\end{tabular}

where $\theta i$ : Initial contact angle; $\theta_{100}$ : Contact angle measured at $100 \mathrm{~s}$; data in parentheses is asymptotic standard error 
Table 3 Characteristic bands of IR absorption spectra and corresponding functionalities in XPS

\begin{tabular}{|c|c|c|c|}
\hline & & FTIR & XPS \\
\hline $\begin{array}{l}\text { Wave number } \\
\left(\mathrm{cm}^{-1}\right)\end{array}$ & $\begin{array}{l}\text { Functional } \\
\text { group }\end{array}$ & Assignment & Functional group \\
\hline 3452 & $\mathrm{NH} / \mathrm{OH}$ & $\begin{array}{l}\mathrm{N}-\mathrm{H} \text { groups in carbazole/ secondary } \\
\text { amine/OH Stretching }[18,51]\end{array}$ & $\mathrm{C}-\mathrm{O} / \mathrm{COOH}$ \\
\hline 3040 & $\mathrm{CH}$ & Aromatic C-H stretching in sp2[18, 52] & $\mathrm{C}=\mathrm{C}$ \\
\hline 2863 & $\mathrm{CH}$ & Aliphatic C-H in sp3[44] & $\mathrm{C}-\mathrm{C}$ \\
\hline 1799 & $\mathrm{C}=\mathrm{O}$ & $\mathrm{C}=\mathrm{O}[51]$ & $\mathrm{C}=\mathrm{O}$ \\
\hline 1431--1505 & $\mathrm{C}=\mathrm{C}$ & $\mathrm{C}=\mathrm{C}$ Stretching Vibrations $[18,53]$ & $\mathrm{C}=\mathrm{C}$ \\
\hline 1126 & $-\mathrm{O}-$ & Esters C-O, ether, COOH[54] & $\mathrm{C}-\mathrm{O}$ \\
\hline $700-900$ & Substitution & $\begin{array}{l}\text { Substitution of the aromatic ring }[43,51 \text {, } \\
54,55]\end{array}$ & $\mathrm{C}=\mathrm{C}$ \\
\hline
\end{tabular}


Table 4 List of functional groups in different bio-cokes, petroleum coke, and pitch found from FTIR study

\begin{tabular}{|c|c|c|c|c|c|c|c|}
\hline Column & 1 & 2 & 3 & 4 & 5 & 6 & 7 \\
\hline Wave number $\left(\mathrm{cm}^{-1}\right)$ & $\begin{array}{c}3200- \\
3500\end{array}$ & $\begin{array}{c}3000- \\
3100\end{array}$ & $\begin{array}{l}2800- \\
2900\end{array}$ & 1799 & $\begin{array}{c}1431-- \\
1505\end{array}$ & 1126 & $700-900$ \\
\hline Functional group & $\begin{array}{c}\mathrm{NH} / \mathrm{OH} / \\
\mathrm{COOH}\end{array}$ & $\begin{array}{l}\text { Aromatic } \\
\text { C-H } \\
\text { stretching }\end{array}$ & $\begin{array}{c}\text { Aliphatic } \\
\text { C-H }\end{array}$ & $\mathrm{C}=\mathrm{O}$ & $\begin{array}{l}\quad C=C \\
\text { Stretching } \\
\text { Vibrations }\end{array}$ & $\begin{array}{l}\text { Esters } \\
\text { C-O, } \\
\text { ether, } \\
\text { COOH }\end{array}$ & $\begin{array}{l}\text { Substitution } \\
\text { of the } \\
\text { aromatic } \\
\text { ring }\end{array}$ \\
\hline Pitch & + & + & + & + & weak & + & + \\
\hline Uncalcined bio-coke-1 & + & + & + & - & + & + & + \\
\hline Uncalcined bio-coke-2 & + & + & + & - & + & + & + \\
\hline Uncalcined bio-coke-3 & + & + & + & - & + & + & + \\
\hline Calcined bio-coke-1 & -@ & - & - & + & - & - & - \\
\hline Calcined bio-coke-2 & -@ & - & - & + & - & - & - \\
\hline Calcined bio-coke-3 & -@ & - & - & + & - & - & - \\
\hline Petroleum coke & + & + & + & - & - & - & - \\
\hline
\end{tabular}

where '+' means that the FTIR spectrum shows the peak at that band, '-' means that the peak of the FTIR spectrum at that band is not observed or not clear, and ‘@’ means diffused peak. 
Table 5 Atomic percentages of different components of bio-cokes, petroleum coke, and pitch

\begin{tabular}{|c|c|c|c|c|c|c|c|c|c|}
\hline \multirow[t]{3}{*}{ Sample } & \multicolumn{5}{|c|}{ Carbon components (\%) } & \multirow{2}{*}{\multicolumn{4}{|c|}{$\begin{array}{r}\text { Atomic percentages } \\
\text { Hetero atoms }\end{array}$}} \\
\hline & \multicolumn{2}{|c|}{ Aromatic Aliphatic } & \multirow{2}{*}{$\begin{array}{l}\text { Amine, ether, } \\
\text { alcohol, thiom } \\
\text { C3 } \\
\text { (CN/CO/CS) }\end{array}$} & \multirow{2}{*}{$\begin{array}{c}\text { Carbonyl } \\
\mathrm{C} 4 \\
(\mathrm{C}=\mathrm{O}) \\
\end{array}$} & \multirow{2}{*}{$\begin{array}{c}\text { Carboxylic } \\
\text { acid }\end{array}$} & & & & \\
\hline & $\begin{array}{c}\mathrm{C} 1 \\
(\mathrm{C}=\mathrm{C}) \\
\end{array}$ & $\begin{array}{c}\mathrm{C} 2 \\
(\mathrm{C}-\mathrm{C}) \\
\end{array}$ & & & & C (\%) & $\mathrm{O}(\%)$ & $\mathrm{N}(\%)$ & S (\%) \\
\hline Pitch & 94.33 & 3.49 & 2.18 & 0.00 & 0.00 & 97.25 & 2.75 & 0 & 0 \\
\hline $\begin{array}{l}\text { Uncalcined bio- } \\
\text { coke-1 }\end{array}$ & 61.69 & 7.64 & 29.87 & 0.31 & 0.5 & 83.13 & 16.82 & 0.05 & 0 \\
\hline $\begin{array}{l}\text { Calcined bio- } \\
\text { coke-1 }\end{array}$ & 82.5 & 12.01 & 5.49 & 0 & 0 & 92.36 & 7.64 & 0 & 0 \\
\hline $\begin{array}{l}\text { Uncalcined bio- } \\
\text { coke-2 }\end{array}$ & 46.39 & 11.19 & 18.8 & 9.22 & 3.54 & 80.99 & 18.93 & 0.07 & 0 \\
\hline $\begin{array}{l}\text { Calcined } \\
\text { bio-coke-2 }\end{array}$ & 84.52 & 22.06 & 14.29 & 0 & 0 & 89.4 & 10.6 & 0 & 0 \\
\hline $\begin{array}{l}\text { Uncalcined bio- } \\
\text { coke-3 }\end{array}$ & 71 & 10.49 & 12.69 & 5.26 & 0.55 & 85.68 & 14.18 & 0.14 & 0 \\
\hline $\begin{array}{c}\text { Calcined } \\
\text { bio-coke-3 }\end{array}$ & 69.73 & 26.3 & 0 & 0 & 3.97 & 87.86 & 12.14 & 0 & 0 \\
\hline Petroleum coke & 87.22 & 9.37 & 2.23 & 0.75 & 0.43 & 95.42 & 2.95 & 0.95 & 0.68 \\
\hline
\end{tabular}




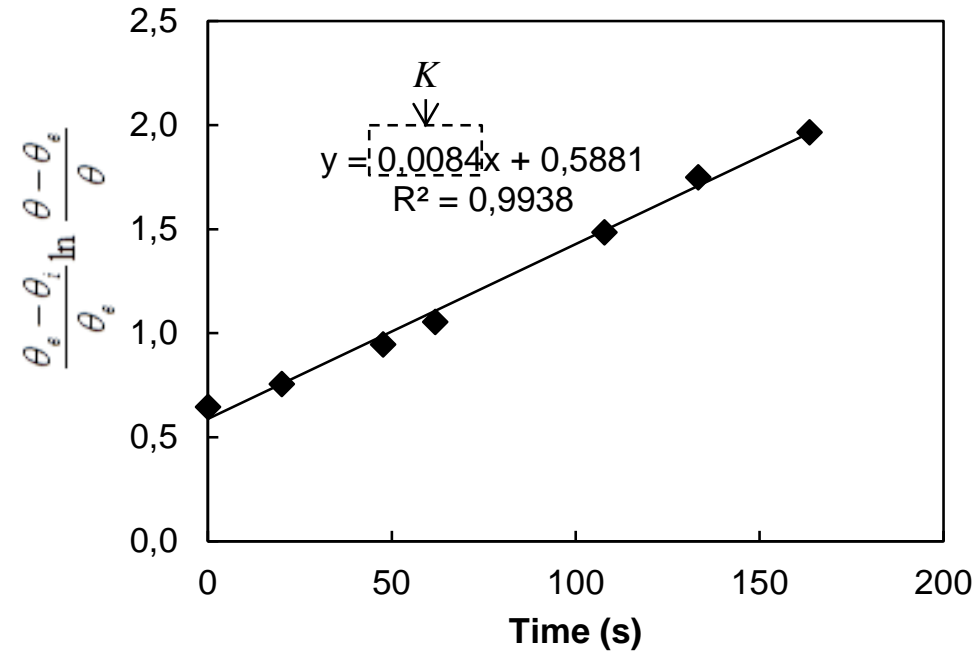

Figure 1 Determination of $K$-value for petroleum coke 

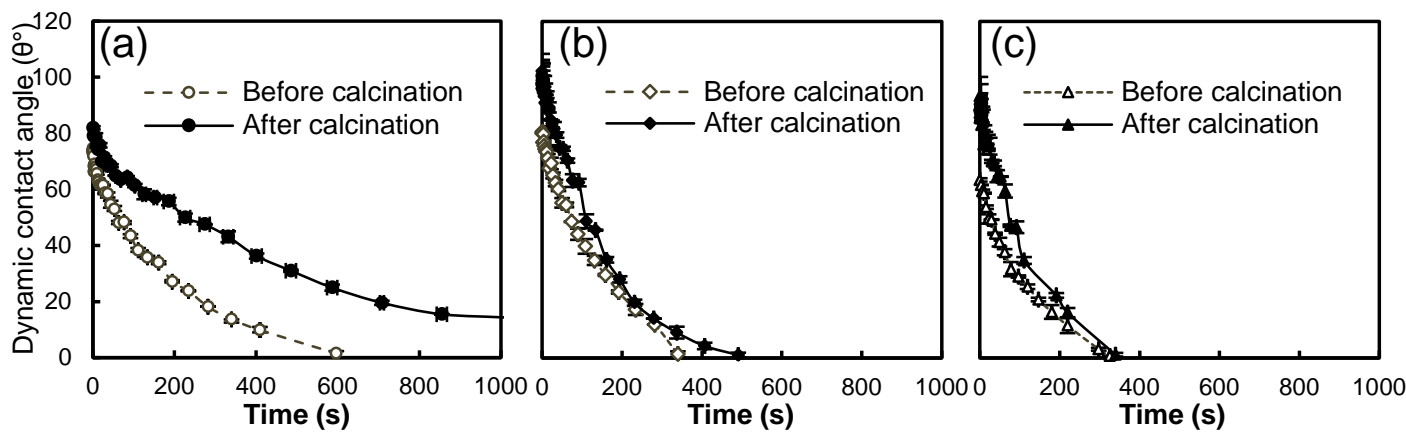

Figure 2 Dynamic contact angle of bio-coke before and after calcination as a function of time: (a) bio-coke-1, (b) bio-coke-2, (c) bio-coke-3 (see Table 1) 


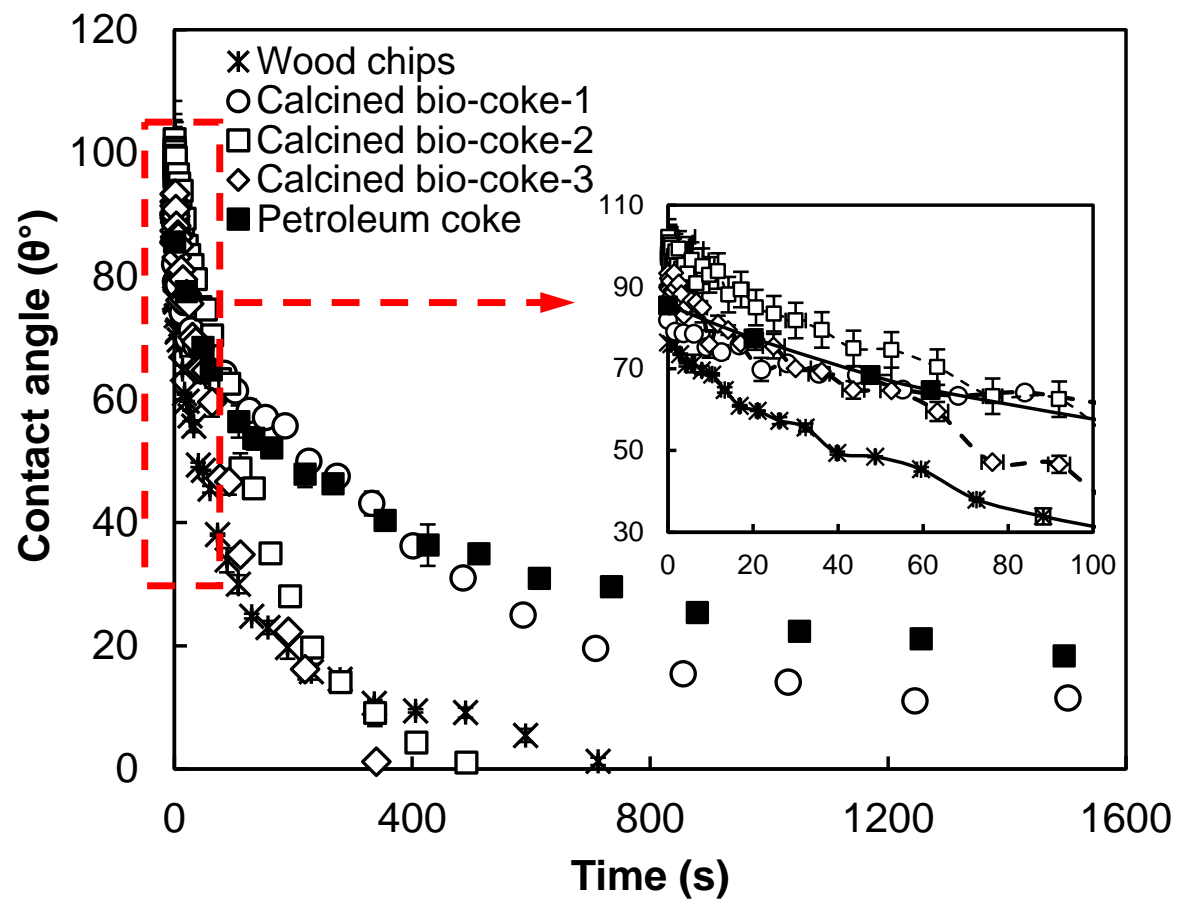

Figure 3 Comparison of dynamic contact angles for three calcined bio-cokes, wood chips, and the petroleum coke (see Table 1) with a coal tar pitch 

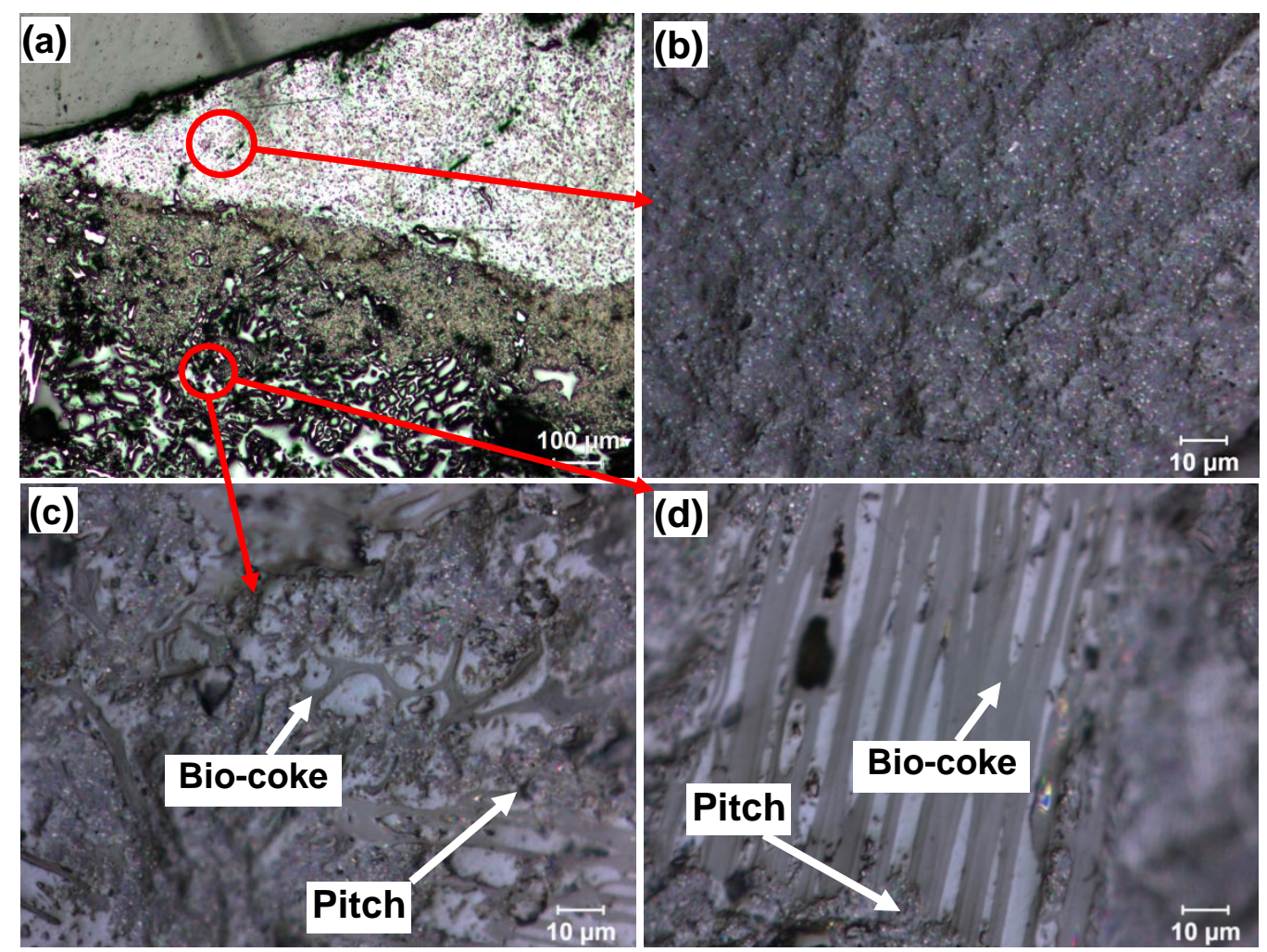

Figure 4 Optical microscopy images on a surface cut through the drop and the bio-coke substrate (cut is vertical to the substrate surface): (a) across the pitch drop and the bio-coke substrate interface, (b) through pitch in the drop, (c) a transverse surface of bio-coke in bed, (d) a longitudinal surface of bio-coke in bed 


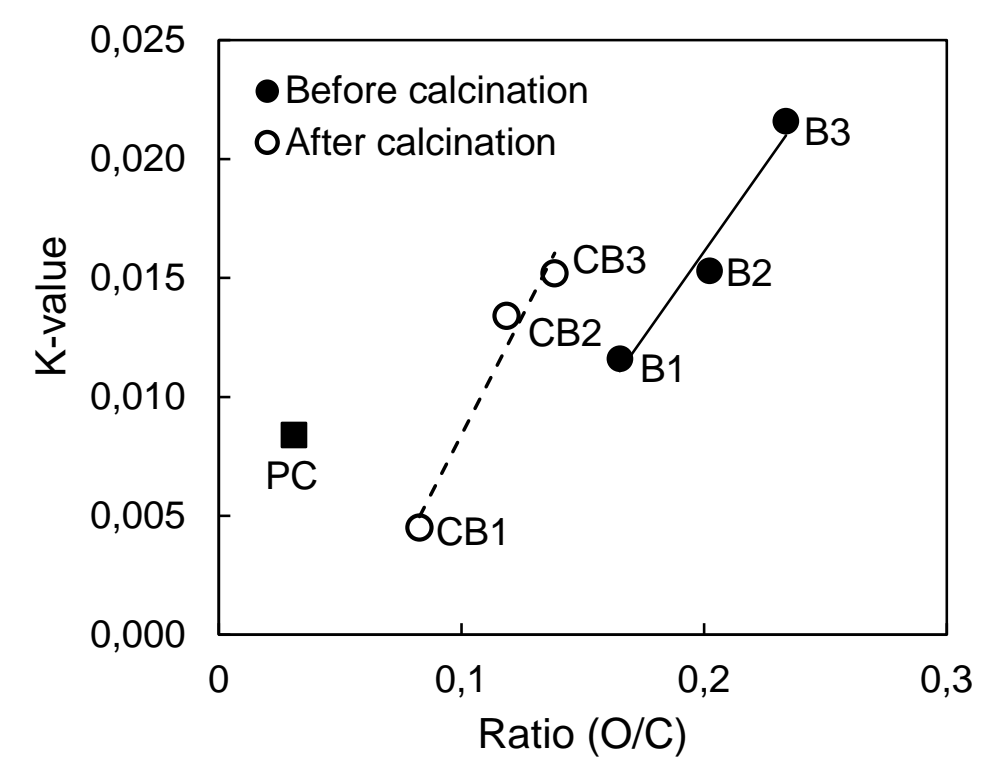

Figure $5 \mathrm{~K}$-values of bio-cokes before and after calcination with different $\mathrm{O} / \mathrm{C}$ ratios

(PC: petroleum coke, B1: uncalcined bio-coke-1; B2: uncalcined bio-coke-2; B3: uncalcined bio-coke-3; CB1: calcined bio-coke-1; CB2: calcined bio-coke-2; CB3: calcined bio-coke-3) 

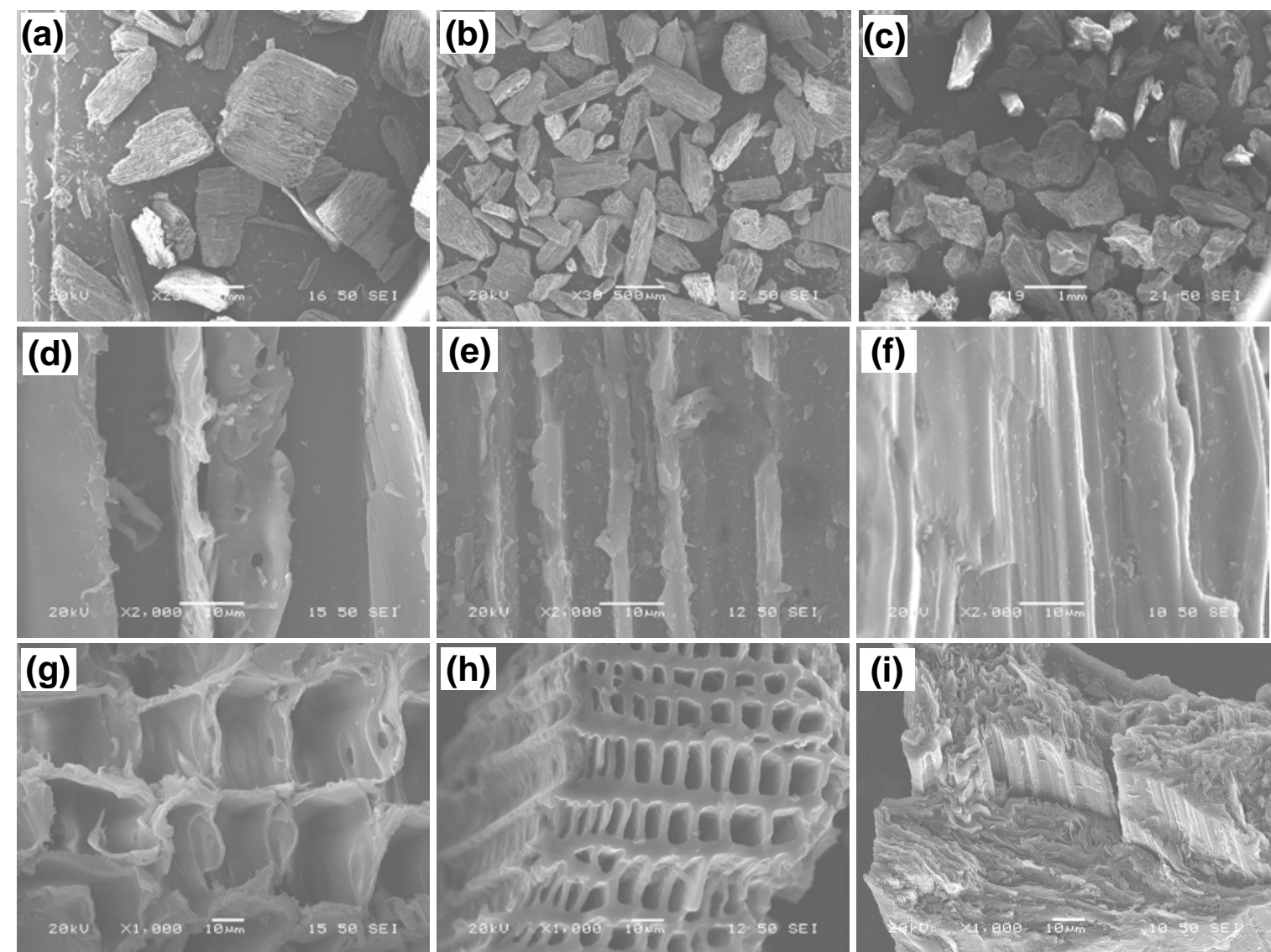

Figure 6 Low-magnification SEM micrographs of (a) uncalcined bio-coke-2, (b) calcined bio-coke-2, (c) petroleum coke, longitudinal surfaces of (d) uncalcined bio-coke-2, (e) calcined bio-coke-2, (f) petroleum coke, and transverse surfaces of (g) uncalcined bio-coke-2, (h) calcined bio-coke-2, (i) petroleum coke 

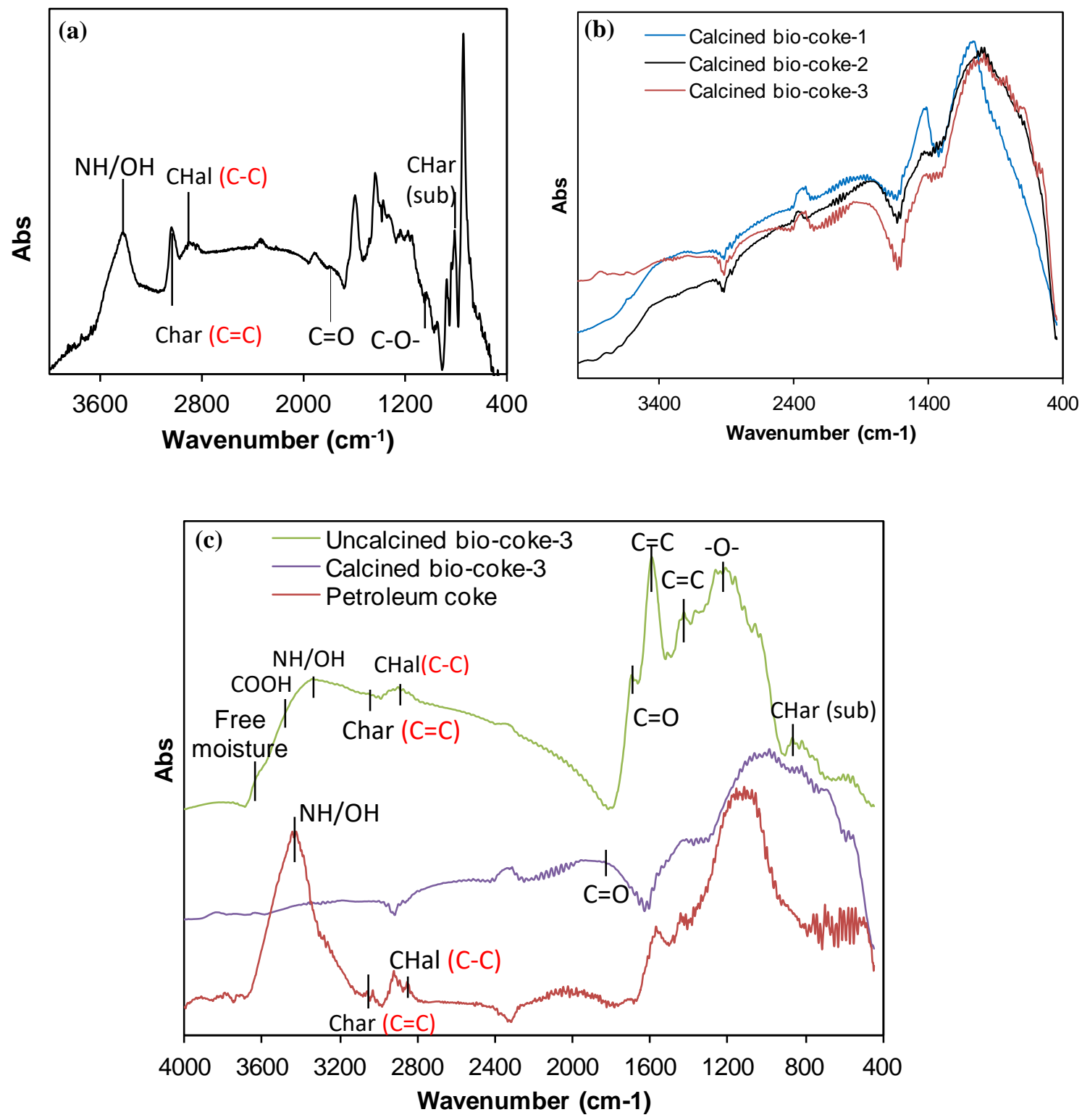

Figure 7 FTIR spectra of (a) pitch at room temperature (b) bio-cokes after calcination (c) comparison of uncalcined bio-coke-3, calcined bio-coke 3, and petroleum coke 

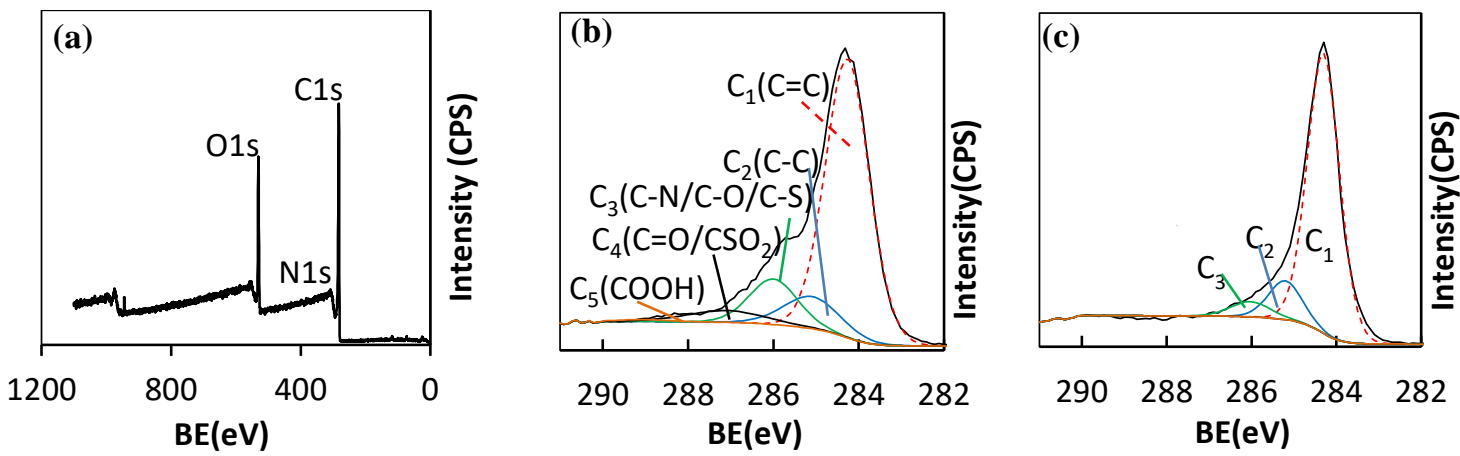

Figure 8 XPS survey spectra of uncalcined bio-coke-3 (a) and C1s spectra of bio-coke-3 before (b) and after (c) calcination 